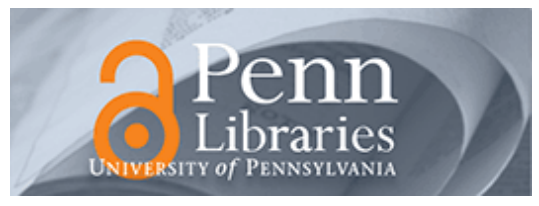

University of Pennsylvania

ScholarlyCommons

Accounting Papers

Wharton Faculty Research

$9-2009$

Does Self-Efficacy Affect Entrepreneurial Investment?

Gavin Cassar

University of Pennsylvania

Henry Friedman

Follow this and additional works at: https://repository.upenn.edu/accounting_papers

Part of the Accounting Commons

Recommended Citation

Cassar, G., \& Friedman, H. (2009). Does Self-Efficacy Affect Entrepreneurial Investment?. Strategic

Entrepreneurship Journal, 3 (3), 241-260. http://dx.doi.org/10.1002/sej.73

This paper is posted at ScholarlyCommons. https://repository.upenn.edu/accounting_papers/49

For more information, please contact repository@pobox.upenn.edu. 


\title{
Does Self-Efficacy Affect Entrepreneurial Investment?
}

\author{
Abstract \\ Society. \\ Keywords \\ entrepreneur, investment, self-efficacy, venturing \\ Disciplines \\ Accounting
}

We empirically examine the effect of self-efficacy on entrepreneurial investment choices. We identify various attributes of entrepreneurial investment and argue that higher self-efficacy is associated with more aggressive entrepreneurial investment decisions. We show that self-efficacy increases the likelihood of being a nascent entrepreneur and creating an operating business. Self-efficacy also increases the proportion of personal wealth invested in the venture and the amount of hours per week the entrepreneur devotes to the venture. These results are significant even when controlling for other known characteristics associated with entrepreneurial investment. Copyright (C) 2009 Strategic Management 


\title{
DOES SELF-EFFICACY AFFECT ENTREPRENEURIAL INVESTMENT?
}

\author{
Gavin Cassar* \\ The Wharton School \\ University of Pennsylvania \\ Henry Friedman \\ The Wharton School \\ University of Pennsylvania
}

April 2009

\begin{abstract}
We empirically examine the effect of self-efficacy on entrepreneurial investment choices. We identify various attributes of entrepreneurial investment, and argue that higher selfefficacy is associated with more aggressive entrepreneurial investment decisions. We show that self-efficacy increases the likelihood of both being a nascent entrepreneur and creating an operating business. Self-efficacy also increases the proportion of personal wealth invested in the venture and the amount of hours per week the entrepreneur devotes to the venture. These results are significant even when controlling for other known characteristics associated with entrepreneurial investment. In contrast, we find no relationship between self-efficacy, or even risk preferences, and investment risk.
\end{abstract}

Keywords: entrepreneur, investment, risk preferences, self-efficacy, venturing.

* Corresponding author: 1309 Steinberg Hall-Dietrich Hall, 3620 Locust Walk, Philadelphia, PA 19104-6365; Phone: (215) 898-2023; Fax: (215) 573-2054; e-mail: cassar@wharton.upenn.edu. 


\section{Introduction}

All entrepreneurial endeavors require investment. We examine the effect of individuals' entrepreneurial self-efficacy (ESE) on their entrepreneurial investment choices. We define entrepreneurial investment as the deployment of resources by an individual to their new venture. Despite the breadth of investment decisions faced by entrepreneurs, little is known about their investment choices. We detail different attributes of entrepreneurial investment beyond simply the choice and amount of financial capital invested. We argue that ESE affects several entrepreneurial investment choices, including entry decision, allocation of personal time and money, and investment risk.

Self-efficacy is a cognitive construct that describes a person's confidence in their ability to perform tasks. Self-efficacy has been shown to influence a broad range of individual's cognition and behavior. For example, self-efficacy is associated with increased expectations and goals (Bandura, 2001), improved work-related performance (Stajkovic \& Luthans, 1998), greater job search activity (Eden \& Aviram, 1993), better academic performance (Luszczynska, Gutiérrez-Doña, \& Schwarzer, 2005), and health-related choices (e.g. Clark \& Dodge, 1999; McAuley, Courneya, Rudolph, \& Lox, 1994; Wulfert \& Wan, 1993). Self-efficacy can be either task-specific, relate to many related tasks within a domain, or be generalized. In this study, we focus on entrepreneurial self-efficacy, which relates to the confidence an individual has in their ability to accomplish tasks in the domain of entrepreneurship and venturing.

We utilize the Panel Study of Entrepreneurial Dynamics (PSED), a longitudinal survey of entrepreneurs, to study the effect of ESE on entrepreneurial investment. The PSED provides data on entrepreneurial investment and self-evaluative items to measure ESE, which we validate 
through an out-of-sample survey. Validated measurement of psychology-based constructs is one of the major issues of applied research on the role of individual beliefs on economic choices (Puri \& Robinson, 2007). The PSED sampling allows examination of how entrepreneurs are different from non-entrepreneurs and also investigation of whether cross-sectional variation in ESE among entrepreneurs leads to variation in investment choice. Additionally, adopting a field design addresses criticism of experimental designs that may lack task representativeness due to deficient incentives, use of salient signals, or subjects' inexperience (Simon \& Houghton, 2003).

This study contributes to our understanding of entrepreneurial investment in several ways. First, it contributes to the literature that investigates the relationship between psychology and entrepreneurship (e.g., Lowe \& Ziedonis, 2006). Although previous studies have examined the ESE-intention relationship (Zhao, Seibert, \& Hills, 2005) and the ESE-performance relationship (Hmieleski \& Baron, 2008), few have investigated how ESE affects specific choices and actions the entrepreneur may take during venturing. Our longitudinal field design uses stratified sampling and sampling weights, rather than students or convenient samples of existing entrepreneurs common in prior research. This mitigates concerns over potential reverse causality between ESE and action and allows estimation of the economic magnitude of ESE on investment choices for the population of U.S. adults and nascent entrepreneurs. For example, we find that an increase in ESE from the $25^{\text {th }}$ percentile to the $75^{\text {th }}$ percentile in the population of U.S. individuals is associated with a 251 percent increase in the likelihood of being a nascent entrepreneur. Furthermore, an increase in ESE from the $25^{\text {th }}$ percentile to the $75^{\text {th }}$ percentile in nascent entrepreneurs is associated with a 60 percent increase in both the percentage of personal wealth invested and the hours per week devoted by the entrepreneur to their start-up. Our research design overcomes concerns from examining individuals at one point in time, in that we 
can empirically determine the extent an entrepreneur invests because they possess high ESE without the contaminating effect of individuals having high ESE as a result of previous investment. Consistent with the importance of controlling for ESE feedback effects in the research design we find that individuals who achieve an operating business from their nascent activity have a subsequent increase in their ESE in later surveys relative to those individuals who did not. Overall, we find that ESE has a substantial causal effect on a range of entrepreneurial investment choices.

Second, extant empirical research on entrepreneurial investment decisions has focused attention on the amount of financial capital invested (Bates, 1995; Bruderl, Preisendorfer, \& Ziegler, 1992; Cooper, Woo, \& Dunkelberg, 1989; McCarthy, Schoorman, \& Cooper, 1993). Yet, financial capital allocation is only one dimension of the many investment choices entrepreneurs make. For example, entrepreneurs also choose how much labor to allocate to their ventures and the riskiness of their entrepreneurial investment. Surprisingly, investment of the entrepreneur's time and venture riskiness have received little empirical attention (Shepherd, McMullen, \& Jennings, 2007). Yet, economists regard both these choices to be fundamental to understanding entrepreneurial investment, entry, and action (Moskowitz \& Vissing-Jorgensen, 2002). By investigating an array of entrepreneurial investment attributes, this study provides novel evidence on investment choice at venture creation. Consistent with the notion that ESE affects individual action, we find that ESE plays a broad and significant role in entrepreneurial investment, influencing entrepreneurial entry and the allocation of personal time and money.

Third, this study contributes to the literature on risk taking. Research on risky behavior in economic setting has explored the role of manager preferences on large, listed firm financial and operational choices. Given entrepreneurial activity is generally regarded as highly risky and there 
is a stronger nexus between founder preferences and venture actions, studying new ventures provides a powerful setting for testing cross-sectional variation in risky choices. Surprisingly, we observe across several dimensions of risk taking, namely riskiness of industry entry, the importance of research and development (R\&D) and whether the venture is high-tech, that neither ESE nor even risk preferences are significantly associated with riskier choices. While survey experiments have generally found a relationship between individuals' risk preferences and risky choice, our results suggest that other factors, such as specific human capital, may inhibit the risk preferences of entrepreneurs being reflected in economic choices in the field.

The following section describes ESE. We describe the different attributes of entrepreneurial investment and their posited association with ESE in section three. In section four we detail the sample, variables used to represent ESE, and the dependent and control variables. We provide the findings in section five, and a discussion of the implications and limitations of the study in section six. Section seven concludes.

\section{Entrepreneurial Self-Efficacy}

Self-efficacy refers to a person's belief that they can perform tasks and fulfill roles, and is directly related to expectations, goals and motivation (Bandura, 1997, 2001). Individuals with high self-efficacy in a particular task are more likely to undertake actions related to the particular task, persist for longer in those tasks, and exert greater effort (Wood \& Bandura, 1989b). Selfefficacy has been shown to affect a wide range of choices, including work-related performance (Stajkovic \& Luthans, 1998), small business growth (Baum \& Locke, 2004; Baum, Locke, \& Smith, 2001), job search activity (Eden \& Aviram, 1993), academic performance (Hackett \& 
Betz, 1989; Luszczynska et al., 2005), choice of academic major (Hackett, 1985), and career choice (Lent \& Hackett, 1987).

An important aspect of self-efficacy is its level of specificity. At the broadest level, selfefficacy can be completely general (Sherer, Maddux, Mercandante, Prentice-Dunn, Jacobs, \& Rogers, 1982), referring to confidence about any and all tasks. At the narrowest level, selfefficacy refers to beliefs about one's confidence in completing one specific task successfully. However, as tasks are often interrelated by domain, self-efficacy can also refer to an individual's confidence in abilities that apply to several related tasks within a domain. This latter example is referred to as domain-specific self-efficacy.

In this study, we focus on a domain-specific self-efficacy, entrepreneurial self-efficacy, which describes a person's confidence about their ability to perform the various tasks and roles relevant to entrepreneurship. We motivate the use of ESE, rather than general self-efficacy, to explain entrepreneurial investment because domain-specific self-efficacy has been shown to have greater predictive power than general self-efficacy when describing career choices (Betz \& Hackett, 1983; Gist, 1987). Importantly, due to its domain specificity, ESE is not venturespecific; individual's ESE should apply at all entrepreneurial activity regardless of idiosyncratic factors related to each unique venture.

One important issue is how ESE is related to, or distinct from, other psychological constructs that may affect investment choices. One of the main differences that distinguish ESE from other constructs is domain specificity. ESE focuses specifically on entrepreneurship, while constructs such as overconfidence, core self-evaluation, self-esteem, dispositional optimism, and locus of control relate to a person's overall disposition. More generally, ESE differs from locus of control because self-efficacy refers to beliefs about achievable levels of performance or 
behavior, while locus of control concerns beliefs about the achievements of outcomes in addition to performance levels (Rotter, 1966). Self-efficacy differs from self-esteem because self-esteem is an affective self-evaluation, such as "I take a positive attitude towards myself" (Rosenberg, 1965), whereas self-efficacy is a judgment about one's capability to complete a task (Gist \& Mitchell, 1992). Dispositional optimism connotes a generally positive outlook, not a judgment about one's efficaciousness (Puri \& Robinson, 2007). Core self-evaluation is a construct that encompasses locus of control, generalized self-efficacy, self-esteem and emotional stability (Judge \& Bono, 2001). This broader construct, due to its abstractness, is not closely related to ESE, except that individuals with high core self-evaluation may be expected to have high ESE, as they would be more likely to have high domain-specific self-efficacy.

Overconfidence has been defined as occurring when individuals overestimate the accuracy of their predictions or more generally when individuals hold excessive confidence in relation to abilities, knowledge, and beliefs (Hayward, Shepherd, \& Griffin, 2006). Importantly, those individuals with a greater propensity for overconfidence with respect to entrepreneurial ability will likely have greater self-efficacy than others, holding actual ability constant. However, self-efficacy does not require any assumption of cognitive bias. Whether justified or otherwise, an individual's belief that they can accomplish tasks in their chosen domain is expected to influence the relationship between beliefs and action.

Survey evidence has found that ESE is positively related to entrepreneurial intention amongst students (Zhao et al., 2005). However, the extent that the intentions of students and the influence of ESE are reflected in the actions of a more general sample of entrepreneurs in an actual field setting can be questioned. Survey evidence has also shown that founder-managers of small businesses have higher ESE than non-founders who manage similar businesses (Chen, 
Greene, \& Crick, 1998). However, from this evidence it is difficult to distinguish whether the founders started their ventures because of high ESE or whether they have high ESE because they successfully founded their ventures (Forbes, 2005b). The latter is a concern because ESE is theorized to be influenced by feedback from entrepreneurial experiences (Zhao et al., 2005). By measuring ESE at the beginning of the entrepreneurial process, we mitigate the possibility that current venture performance influences ESE, thereby addressing concerns of reverse causality in previous studies. Further, our use of different instruments of varying mediums over time to obtain the dependent and independent variables addresses several concerns related to results being induced by common method bias in the research design, which is present in previous ESE research (Podsakoff, MacKenzie, Lee, \& Podsakoff, 2003).

We investigate self-efficacy in the entrepreneurial setting because there is a stronger nexus between the entrepreneur's decisions and the new venture's actions than exists in established firms, where formal processes and other actors mediate the influence of managerial bias on firm action (Simon, Houghton, \& Savelli, 2003), and because the entrepreneurial setting is characterized by uncertainty, which is associated with an increased prevalence of personal beliefs in decision-making (Busenitz \& Barney, 1997; Knight, 1921). The combination of high uncertainty and the direct connection between the entrepreneur's beliefs and the venture's actions make the entrepreneurial setting a powerful one in which to study the effect of selfefficacy on investment.

\section{Hypotheses}

The beliefs that entrepreneurs hold during entrepreneurship can be at least partly explained by beliefs that individuals have beforehand and bring into entrepreneurship (Forbes, 
2005a). The existence of high ESE amongst entrepreneurs (Chen et al., 1998) could be the result of self-selection from traditional employment to nascent entrepreneurship, self-selection from nascent to operating entrepreneurship, or obtained once in entrepreneurship (Forbes, 2005b). In the process of discovering, creating, or exploiting an entrepreneurial opportunity, regardless of the financial or non-financial career reasons for starting the business (Cassar, 2007), an individual is faced with several distinct investment choices including how much of their personal wealth and time to devote to the venture, whether and how much external funding to utilize, and the riskiness of their venturing activity. Underlying these choices is the entrepreneurial entry decision, as without entrepreneurial entry there is no entrepreneurial investment.

Investment in the Nascent Stage

Although entrepreneurial entry may not traditionally be considered an investment choice, entrepreneurial entry is a necessary precondition for investment, and therefore, a proxy for the existence of entrepreneurial investment. That is, an individual must first decide to pursue entrepreneurship before making personally costly venture-specific investments. Individuals with high ESE will tend to perceive themselves as able to exploit potential entrepreneurial opportunities as they can perform the tasks and exert the effort required to create a venture from the opportunity, and thus will be more likely to involve themselves in start-up activities. Empirical evidence has shown that domain-specific self-efficacy affects the challenges that an individual is willing to undertake (Bandura \& Cervone, 1986) and that self-efficacy is a significant predictor of academic and career choices (Hackett, 1997). ESE has been found to be associated with entrepreneurial intentions in college students, and small business founders have higher ESE than non-founders (Chen et al., 1998; Zhao et al., 2005). We expand on previous research by providing evidence of ESE's causal effect on entry in the nascent stage of 
entrepreneurship by a representative sample in a field setting. We refer to individuals involved the start-up phase of a new business as nascent entrepreneurs.

Hypothesis 1: Entrepreneurial self-efficacy is positively associated with involvement in nascent entrepreneurship.

\section{Investment in the Operational Stage}

Action is a necessary condition for operational entrepreneurship (McMullen \& Shepherd, 2006), and action is costly. While undertaking startup activities, nascent entrepreneurs can learn whether the benefits of creating an operating business to exploit the entrepreneurial opportunity outweigh the costs. The decision to exploit the opportunity through operation requires that nascent entrepreneurs expect the entrepreneurial profit to be enough to compensate them for their opportunity costs, uncertainty premium if they are risk averse, and the illiquidity of their financial investment (Cassar, 2006; Kirzner, 1978). When the nascent entrepreneur creates an operating business from their startup activity they can be characterized as an operational entrepreneur. The presence of an operating business signifies significant investments in the venture have been made.

Self-efficacy is strongly related to goals, in that individuals with higher self-efficacy set higher goals for themselves and are more committed to achieving those goals compared to individuals with low self-efficacy (Wood \& Bandura, 1989a, 1989b; Wood, Bandura, \& Bailey, 1990). Individuals with high self-efficacy tend to persevere when faced with difficulties, put greater effort into achieving goals, and achieve greater levels of performance (Bandura \& Cervone, 1986; Locke, Frederick, Lee, \& Bobko, 1984). High ESE nascent entrepreneurs may be 
more likely to sustain the belief that they can overcome the risks and challenges of entrepreneurship, even as they learn about new risks and challenges during the startup phase. Therefore we expect individuals with high ESE to be more likely to persist in entrepreneurial venturing and deploy the necessary resources in order to transform the venture into an operational business.

Hypothesis 2: Entrepreneurial self-efficacy increases the likelihood that a nascent entrepreneur will create an operational business from their startup activity.

\section{Financial Capital Investment}

Entrepreneurial financial capital investment refers to the monetary resources deployed by the entrepreneur in order to discover, create or exploit an entrepreneurial opportunity. The entrepreneur has discretion regarding the amount of financial capital to commit to the venture and sources of that financial capital.

As discussed above, self-efficacy is associated with goal-setting and goal commitment. Higher goals may manifest through greater projected venture scope, complexity, or size. An individual with high ESE may be more likely to believe that she can handle a larger, more complex venture, and set goals to that effect. The larger venture, in turn, may require greater resources, including financial capital. Furthermore, greater personal commitment to self-set goals may manifest through increased personal investment. Entrepreneurs with higher ESE will be more committed to their ventures and thus invest more of their personal wealth. The effect of ESE on goal setting and goal commitment will therefore lead to individuals with high ESE investing more of their own financial wealth in their ventures. 
Another possibility is that personal financial investment can be affected by risk perception, which may depend on ESE. Individuals with higher perceived decision-making selfefficacy are more likely to perceive opportunities rather than threats in risky choices (Krueger \& Dickson, 1994). ESE may encompass decision-making self-efficacy when the relevant choices are in the entrepreneurial domain. Therefore individuals with higher ESE are likely to perceive opportunities rather than threats in entrepreneurship; they may perceive less risk than individuals with lower ESE. So, even if two individuals are considering the same investment, the individuals may have differing beliefs about the probability of success due to conditioning on ESE. In other words, the individual with high ESE may believe that the probability of success is greater. One reason for the difference between the unconditional and conditional risk perception is that the entrepreneur with high ESE may believe that she can motivate the effort necessary to overcome the obstacles that might prevent success, while the entrepreneur with low ESE expects to fail when faced with difficult obstacles to success. Conditional on survival, the returns from entrepreneurial financial investment are significantly greater than returns from passive investments such as the stock market (Moskowitz \& Vissing-Jorgensen, 2002). However, when investment in failed firms is taken into consideration, the returns are significantly lower than other investments. Believing that venture success is more likely, entrepreneurs with high ESE would assign additional weight to the venture return conditional on survival as opposed to the unconditional return, which, based on financial economic theory would shift their portfolio towards investment in the venture. Therefore, we expect entrepreneurs with high ESE to commit a greater share of their financial capital to the venture and worry less about being diversified in their entrepreneurial investment. 
Alternatively, entrepreneurs with higher ESE may believe they can overcome obstacles and achieve success with fewer financial resources. Consequently, they may underestimate the financial resource endowments their ventures require. This would cause these entrepreneurs to invest less financial capital. If this alternative explanation is dominant, consistent with earlier predictions, we should observe a lower, rather than a higher, share of personal wealth devoted to the venture. However, the self-efficacy literature suggests an effect on goal setting and commitment, rather than an investment reduction effect (Bandura \& Cervone, 1986; Wood \& Bandura, 1989b). In other words, we expect individuals to engage in ventures that require more funds or to be more willing to commit funds. We do not expect individuals to hold the venture scale constant and reduce their investment levels.

Hypothesis 3: Entrepreneurial self-efficacy is positively associated with the share of personal financial capital entrepreneurs will invest in their ventures.

\section{Personal Labor Investment}

Entrepreneurial investment is not limited to financial capital. Entrepreneurs must also decide how much of their personal time and effort to devote to the venture. For an individual to invest personal labor in a new venture, they must perceive that the returns outweigh the opportunity costs, including leisure and lost wages from alternative vocational activity. As mentioned above, ESE affects goal setting and goal commitment. These should have a positive effect on personal labor investment for similar reasons as the positive effect they may have on personal financial investment. Therefore we predict that entrepreneurs with higher ESE will invest more time in their ventures. 
Hypothesis 4: Entrepreneurial self-efficacy is positively associated with the amount of labor entrepreneurs will invest in their ventures.

\section{Investment Risk}

Risky investments can be defined as those with greater outcome uncertainty, positive outcomes that are more difficult to attain, or a potential for more severe consequences (March \& Shapira, 1987; Moskowitz \& Vissing-Jorgensen, 2002; White, Thornhill, \& Hampson, 2006). An investment might have greater risk due to a higher degree of variation when there is a relatively high probability that an outcome far from the expected outcome will occur (Kallman, 2007). An investment can also be risky if it has a high probability of resulting in a loss, or if the magnitude of a possible loss is large (MacCrimmon \& Wehrung, 1990). Furthermore, an investment can be risky if there is a lack of information with which to predict the outcome, such as in the introduction of a revolutionary product, as this would necessarily lead to a wide distribution of possible outcomes.

The variance of returns, a common proxy for investment risk, can be decomposed into systematic variance and idiosyncratic variance. The portion of variance that is correlated with other assets, making it potentially hedge-able and therefore diversifiable, comprises the systematic variance. The remaining variance is idiosyncratic, which can be minimized if individuals hold a well-diversified portfolio. Entrepreneurs often hold un-diversified portfolios (Moskowitz \& Vissing-Jorgensen, 2002), which exposes them to significant risk, a defining characteristic of entrepreneurship (Knight, 1921; Schumpeter, 1934). 
We expect entrepreneurs with higher ESE to believe that negative outcomes are less likely, because they can be overcome by the entrepreneur's skills and abilities (Camerer \& Lovallo, 1999). Individuals with low self-efficacy, on the other hand, may be preoccupied with failure scenarios or be easily discouraged by potential failure (Bandura \& Cervone, 1986). They would thus shy away from potentially risky situations. Perceived risk, therefore, may be negatively associated with ESE levels. Thus, entrepreneurs with higher ESE will involve themselves in riskier ventures than entrepreneurs with comparatively lower ESE who would avoid riskier ventures (Krueger \& Dickson, 1994). More specifically, individuals with high ESE may be more likely to engage in ventures that have high unconditional or objective risk, because the perceived, subjective risk conditional on ESE is relatively lower.

However, the ability for an entrepreneur to choose the level of their investment's risk may be constrained by the variation in risk across an industry and his human capital and switching costs. Some industries offer less opportunity to undertake more risky behavior. For example, the opportunity to invest in uncertain pay-offs, such as research and development, is greater in high technology industries than in occupational industries such as hairdressing. Further, an individual who is trained and experienced in a low-risk occupational job may find it too costly, given the opportunity costs of not utilizing their current skills and making additional investment in human capital, to switch to a more risky field. Furthermore, the choice to enter an industry is likely influenced by psychic income and intrinsic factors (Carter, Gartner, Shaver, \& Gatewood, 2003; Gimeno, Folta, Cooper, \& Woo, 1997). That is, individuals may choose specific industries due to a preference for a certain type of work and this preference may dominate risk explanations. Regardless, we expect individuals with greater ESE and with a preference for more risk to pursue riskier ventures. Similar to other choices, the nexus between 
individual beliefs and risk should be stronger in smaller firms with more concentrated ownership than in larger, less concentrated firms (Coles, Daniel, \& Naveen, 2006; Miller \& Bromiley, 1990).

Hypothesis 5. Entrepreneurial self-efficacy is positively associated with venture risk.

\section{Method}

Sample

We used the Panel Study of Entrepreneurial Dynamics (PSED) to investigate how ESE affects entrepreneurial investment decisions. The dataset is unique in that it obtains responses from nascent entrepreneurs who are currently in the startup phase of a new venture (Gartner, 2004). Consequently, the PSED overcomes issues associated with survivorship and recall biases, which can be problematic when only entrepreneurs who have already established businesses are analyzed. The PSED also allows for a field study of the relationship between biases and investment choices in entrepreneurship, allowing for better task representativeness than can be accomplished in laboratory studies (Simon \& Houghton, 2003).

The PSED sample frame was all individuals at least 18 years old residing throughout the mainland U.S. The sample was identified through a random digit dialing methodology, with 64,622 households surveyed. To be identified as a nascent entrepreneur and included in this study a respondent had to answer "yes" and then "no" to the following two questions: "1) Are you, alone or with others, now trying to start a new business?; 2) Are you, alone or with others, now starting a new business or new venture for your employer? An effort that is a part of your job assignment?" These criteria ensure that the respondent, rather than an employer, makes the 
entrepreneurial decisions. In addition, the respondent had to: 1) expect to have at least some ownership in the new firm; 2) have been actively trying to start the new firm in the past 12 months; and 3) be currently involved in the startup phase of the venture. ${ }^{1}$ In the first round of the PSED, 830 respondents qualified as nascent entrepreneurs. To allow for comparison between the nascent entrepreneurs and individuals not involved in nascent startup activity, PSED researchers interviewed a control sample of 431 individuals by telephone and sent questionnaires to 422 of them.

Subsequently, the PSED researchers interviewed by phone a sample of nascent entrepreneurs, and sent a questionnaire by mail to a further sub-sample. The PSED followed up with three subsequent waves, interviewing the entrepreneurs by phone and with written questionnaires in each of the three subsequent waves on average 14, 33, and 55 months after the initial interview. On average, in each round, respondents returned the written questionnaires 53 days after they were surveyed by phone. Some respondents did not answer some or all questions in every round of the PSED.

An examination of the potential non-response bias revealed that individuals who were involved in the first round of phone interviews but did not respond to any written questionnaires were likely to be younger $(\mathrm{p}<0.01)$ and have fewer years of managerial experience $(\mathrm{p}<0.05)$. Respondents' (non-respondents') average age and years of managerial experience were, respectively, 40 (36) and 7.7 (6.22). Respondents and non-respondents were not significantly different based on whether they had attended college, whether their parents were entrepreneurs, household income, gender, or marital status.

\footnotetext{
${ }^{1}$ Under these criteria all sample entrepreneurs owned at least 51 percent of the control rights of their ventures. Outsiders had a minority share in 112 of the remaining 823 entrepreneurs' ventures. To investigate the potential for outside ownership to affect entrepreneurial investment decisions, all models were estimated using subsamples that
} 
The independent variable of interest, ESE (and risk preference), was obtained from the mail questionnaire in the first stage of the PSED. All other independent variables are taken from the first round phone interview. The dependent variables are obtained from phone interviews in the first and subsequent waves of the PSED, as noted below. The use of different instruments of varying mediums over time to obtain the dependent and independent variables addresses several concerns related to common method bias (Podsakoff et al., 2003). Further, the longitudinal design allows for some testing of causal relationships between ESE and entrepreneurial investment, thereby addressing reverse causality concerns present in previous ESE studies.

\section{Entrepreneurial Self-Efficacy}

Our measure of ESE is obtained from averaging responses to four items, creating a scale that ranged from one to five. Responses were given on a 5-item likert scale ranging from 1completely disagree to 5-completely agree. The statements were: "1) If I work hard, I can successfully start a business; 2) Overall, my skills and abilities will help me start a business; 3) My past experience will be very valuable in starting a business; 4) I am confident I can put in the effort needed to start a business." Of the 1,261 respondents (nascent entrepreneurs and control group), 888 answered all four ESE questions. The mean (median) of the ESE variable is 4.134 (4.25). The standardized Cronbach Alpha of these responses is 0.77 .

To examine the construct validity of this and other measures used in the current study we performed an out-of-sample validity survey. The details of the validity study and results are reported in Appendix A. The raw correlation between our measure of ESE and the measure of CGC ESE from Chen, Greene and Crick (1998) is over 52 percent, indicating a moderate degree of convergent validity consistent with Puri and Robertson (2007). Further, to ensure that our

excluded ventures with outside ownership. This subset of entrepreneurs yielded similar results to the full sample and consequently are not reported. 
measure of ESE is not proxying for other related constructs established in the literature we used established scales to measure overconfidence, general self-efficacy, locus of control, dispositional optimism, self esteem, and core self evaluation. The correlation coefficients between ESE and these scales were all below 0.30, substantially lower than that observed for the established ESE scale. The difference between the correlation coefficients suggests discriminant validity, consistent with Zhao et al. (2005).

\section{Controls}

Risk preference is operationalized by the average of three questions whose answers are scaled to the interval $[0,1]$, where a greater value indicates a preference for riskier situations. The questions are: 1) whether the respondent prefers a business with little risk of failure and little likelihood of making them a millionaire or a business that was much more likely to make them a millionaire but had a much higher chance of going bankrupt; 2) the importance the respondent places on obtaining information about the chances of going bankrupt when evaluating business opportunities; and 3) the extent that the respondent enjoys the challenge of situations that many consider risky. The raw correlation between our measure of risk preference and the measure of risk preference from the Jackson Personality Index-Revised (Jackson, 1994) is over 59 percent in our validity study sample. ${ }^{2}$

Research has documented several variables that should be controlled for when investigating various entrepreneurial investment choices. For example, the decision to be an entrepreneur has been shown to be associated with human capital, social/cultural capital, financial capital, and demographics (Davidsson \& Honig, 2003; Holtz-Eakin, Joulfaian, \&

\footnotetext{
${ }^{2}$ The cronbach alpha for the PSED-based risk questions is 0.48 in the validation study sample and 0.37 in the PSED sample. However, the correlation coefficient for the combined measure with the JPI-R score $(\rho=0.60)$ is greater than the correlation coefficient for any of the individual PSED-based risk questions with the JPI-R score, suggesting
} 
Rosen, 1994; Hurst \& Lusardi, 2004; Kim, Aldrich, \& Keister, 2006; Parker \& Belghitar, 2006;

Zhao et al., 2005). Therefore, this study controls for the effects of human capital, financial capital, social capital, demographics, and venture characteristics.

The human capital controls are whether the respondent completed college, managerial experience, and household income. We use a dummy variable to indicate whether college was completed. Managerial experience is the log of one plus the number of years the respondent has worked as a manager. We log household income to reduce skewness. Financial capital is controlled for using household wealth. We use the log of the household wealth measure developed in Kim et al. (2006), truncated at zero to avoid negative values. To control for social or cultural capital, we used a dummy relating to whether parents were self-employed (0-No; 1 Yes), consistent with Kim et al. (2006). Demographic controls include a continuous variable of the respondent's age, dichotomous variables for whether the respondent is female and whether the respondent is married, and regional dummies for four U.S. regions (South, Midwest, West, and Northeast).

We also control for the stage of development of the product/service with a series of dummy variables. The stage of product development is given by the response to: "At what stage of development is the product or service this (start-up/new firm) will be selling: 4) Completed and ready for sale or delivery; 3) A prototype or procedure has been tested with customers; 2) A model or procedure is being developed; 1) Still in the idea stage or no work has been done on the product or service?"”

\section{Dependent Variables}

Nascent Entrepreneur takes a value of 1 for individuals involved in nascent startup 
activity and 0 otherwise, for individuals in the control group. The PSED identified operational entrepreneurs, those who had founded operating businesses, with the question, "How would you describe the current status of this start-up effort? Is it now an operating business, still in an active start-up phase, still a start-up but currently inactive, no longer being worked on by anyone, or something else?" This question was asked in each subsequent round of the PSED (rounds two through four). Operating Entrepreneur takes a value of 1 for nascent entrepreneurs who described their ventures as operating business in any subsequent round of the PSED, and 0 otherwise. For respondents who did not provide their status in a later phase of the PSED, Operating Entrepreneur was coded missing. ${ }^{3}$

We use the response to "How much of your own money, in total dollars, have you now put into the business?" at the time of initial questionnaire, divided by the individual's household wealth to obtain a measure of the personal financial commitment (Wealth Share). The ratio of contributed capital to household wealth is a proxy for concentration of financial capital in the venture and thereby the entrepreneur's exposure to venture's idiosyncratic risk that could otherwise be avoided through diversification. Given the potential for ratios to result in extreme values, we truncate the values of wealth share above the $99^{\text {th }}$ percentile. We measured personal labor investment using the response to "In the past week, how many hours have you devoted to this new business start-up?" (Hours per Week). ${ }^{4}$

One potential concern with the above financial capital and hours devoted dependent variables is reverse causality. In particular, whether an entrepreneur devotes more hours per

\footnotetext{
${ }^{3}$ An alternative variable was used to verify the results from this self-reported measure. Under this alternative, any venture that had received funds from the respondent, received money, income, or fees from the sale of goods or services, and filed a federal income tax return was coded as an operating business. The alternative definition was 73 percent concordant with the self-reported operating business definition. In unreported results, the alternative definition yielded results similar to those of the self-reported operational business measure.
} 
week on average because of a high ESE, or if the high ESE results from long hours spent working on the venture. In order to investigate the effect of potential reverse causality on our findings we utilize additional Wealth Share and Hours per Week dependent variables from subsequent waves of the PSED. In particular, Wealth Share Later and Hours per Week Later, are taken from the earliest phone interview from subsequent PSED waves (2-4) where the respondent answered the relevant question. Due to sample attrition between waves, there are fewer observations for these variables than the dependent variables from the first wave. We report results using both approaches given the trade-off between overcoming potential reverse causality and the benefits of greater power from a larger sample size.

We employed five risk variables to measure the risk associated with entrepreneurial investment. First, we use a residual profitability measure based on Bitler, Moskowitz, and Vissing-Jorgensen (2005). Using data from the 1998 Survey of Small Business Finances (SSBF), we ran a cross-sectional regression of return on equity (ROE) ratios of firms on observable characteristics, including log of number of employees, $\log$ of total firm equity, firm age, firm age squared, the entrepreneur's experience, as well as on dummies for entrepreneur education, gender, ethnicity, venture industry, year, and whether the firm was founded by the entrepreneur. The Bitler et al. (2005) measure takes a firm's riskiness as the absolute value of the residual from the regression - a measure of idiosyncratic (un-diversifiable) risk. To allow for use in this study, we take the median value for each 2-digit SIC code to represent an industry's risk.

The second measure we use is the rate of firm deaths amongst firms with 1-4 employees in each 3-digit SIC code industry group as reported in the 1997-1998 portion of the Business

\footnotetext{
${ }^{4}$ We winsorized four values greater than 100 hours of time per week; however, the results are robust to the winsorization.
} 
Information Tracking Series provided by the U.S. Census. Higher firm death rates indicate that negative outcomes are more likely for a given industry.

The third measure of riskiness is an idiosynchronous return measure based on Li et al. (2004). Variance in stock price reflects volatility in the market's expectations and thus riskier cash flows expected in the future. We operationalized the riskiness of an industry in terms of the average variance beyond a market model regression of firm returns for each 3-digit SIC code. This indicates the level of idiosyncratic risk to financial returns for individual firms within an industry. We use the median variance from firm-specific market model regressions within each 3-digit SIC code, for public firms with at least 50 observations of monthly returns between January 1998 and December 2002 from the Center for Research in Security Prices. A higher value of this measure indicates that individual firm returns in an industry have greater idiosyncratic risk. For ease of presentation, all three operational risk measures are multiplied by 100.

Finally, we tested two self-reported dichotomous measures to capture the risk associated with entrepreneurial investment. The first dichotomous measure is whether research and development (R\&D) spending is a high priority. R\&D intensity has been suggested and used by researchers as a risk measure (Amit \& Livnat, 1988; Kamien \& Schwartz, 1971; Loury, 1979; Miller \& Bromiley, 1990; Scherer, 1967), and has been shown to increase the variance of earnings (Kothari, Laguerre, \& Leone, 2002), a common measure of riskiness for established firms. The second dichotomous risk measure is whether the respondent considers the venture to be high-tech. High-tech ventures are generally considered to be intrinsically risky (Carpenter, Pollock, \& Leary, 2003; Mahmood, 2000; Singh, 1986). 
The dependent variables were modeled using logistic regressions for binary dependent variables and ordinary least squares (OLS) regressions for continuous variables. All reported tests use unweighted data and are tested using two-tailed tests. All findings using adjusted surveying weights provided by the PSED are consistent with the unweighted results presented below.

\section{Results}

\section{Descriptive Statistics}

Table 1 presents the descriptive statistics and Pearson correlation coefficients of the study variables. Not all respondents answered every question in the PSED, which leads to variation in the number of responses for each variable. Further, there are missing correlations between Nascent Entrepreneur and several variables because these were only asked to individuals in the nascent entrepreneur group.

ESE is significantly correlated with several of the decision variables in the direction hypothesized. It has a positive correlation with Nascent Entrepreneur $(\rho=0.29, \mathrm{p}<0.001)$, Operating Entrepreneur $(\rho=0.16, \mathrm{p}<0.001)$, Wealth Share $(\rho=0.13, \mathrm{p}<0.01)$, Hours per Week $(\rho=0.26, \mathrm{p}<0.10)$, and Industry Death Rate $(\rho=0.09, \mathrm{p}<0.10)$. Individuals with higher ESE are more likely to have significantly greater risk preferences $(\rho=0.20, \mathrm{p}<0.001)$.

Insert Table 1 about here

Entrepreneurial Entry

Our regression results suggest that ESE is generally associated with more aggressive entrepreneurial investment. We report the results for entrepreneurial entry in Table 2. Columns 1 
and 2 report the coefficients for the logistic model of being a nascent entrepreneur, without and with controls, respectively. Given the similar findings between these models we restrict comments to discussion of the full models. The coefficient on ESE is positive and significant ( $\beta$ $=0.86, \mathrm{p}<0.001)$, consistent with Hypothesis 1 , that individuals with high ESE are more likely to be nascent entrepreneurs. ${ }^{5}$ Risk preference was not significant. ${ }^{6}$ A change in ESE (Risk Preference) from the $25^{\text {th }}$ to the $75^{\text {th }}$ percentile increases the expected likelihood of being a nascent entrepreneur in our sample from 57 (63) percent to 76 (67) percent (when all other variables are at their means), an increase of 33 (5) percent. The weighted results based on a representative sample of U.S. individuals aged 18 or above provide an even stronger ESE effect, with a change in ESE from the 25th $(2.75)$ to the $75^{\text {th }}(3.75)$ percentile increasing the likelihood of being a nascent entrepreneur from 2.06 percent to 7.25 percent (when all other variables are at their weighted means), an increase of 251 percent.

Column 4 reports the coefficients for the full logistic model of becoming an operational entrepreneur. For our sample, 44 percent of nascent entrepreneurs founded operating businesses

\footnotetext{
${ }^{5}$ To investigate the possibility that previous entrepreneurial experience may affect the findings or that those with no previous entrepreneurial experience may more truly capture entrepreneurial entry, we partitioned the sample by whether the respondent was self-employed full-time anytime during the previous ten years. The results of the nascent entrepreneurship model are consistent for both the sub-sample of 333 individuals with no entrepreneurial experience and those 327 individuals with entrepreneurial experience.

${ }^{6}$ To investigate if question differences between the field study of nascent entrepreneurs and the validation study of business students may be contributing to the non-significance of risk preferences on entrepreneurial intentions we performed regressions of entrepreneurial intent using the validation sample. Specifically, we regressed Chen et al. (1998) measure of entrepreneurial intent on gender and: 1) the PSED entrepreneurial self-efficacy and risk preference measures; and 2) the Chen et al. (1998) entrepreneurial self-efficacy and JPI Risk Taking (Jackson, 1994) measures. The results from this untabulated regression show that the association between entrepreneurial intentions and ESE and risk preference is actually stronger for the PSED-based measures, suggesting that the specific choice of risk preference measure is not contributing to the insignificant relationship in the PSED sample. Taken together, the results from the two studies is more consistent with sample or research design differences causing weaker findings in the field sample. In particular, the use of field studies offers greater task representativeness then achieved from using student subjects about their intended behavior (Simon \& Houghton, 2003). Further, the soliciting of responses for the dependent and independent variables using different instruments based on phone and mail surveys an average of one month apart reduces potential sources of educed correlation from common method biases (Podsakoff et al., 2003). Both these effects should reduce the strength of the observed association between the dependent and independent variables in the field sample.
} 
based on their startup activity, which is similar to other PSED-based research (Parker and Belghitar, 2006). Consistent with Hypothesis 2, the coefficient on ESE is positive and significant $(\beta=0.80, p<0.001)$. A change in ESE (Risk Preference) from the $25^{\text {th }}$ to the $75^{\text {th }}$ percentile is associated with an increase (decrease) in the likelihood of being an operational entrepreneur from 33 (42) percent to 53 (40) percent (when all other variables are at their means), an equivalent increase of 60.6 percent in likelihood. This evidence suggests that nascent entrepreneurs with higher ESE are substantially more likely to found operational businesses based on their startup activity. The results from the Nascent and Operating Entrepreneur models suggest that ESE both significantly increases the likelihood of an individual becoming a nascent entrepreneur and increases the likelihood of a nascent entrepreneur founding an operational business based on the startup activity.

Insert Table 2 about here

\section{Financial Capital and Hours Invested}

Table 3 presents the tests for financial and labor investment in entrepreneurship. We report the coefficients from the full OLS regression model of Wealth Share in column 1 and Wealth Share Later in column $2 .^{7}$ The coefficient on ESE is positive and significant in both cases ( $\beta=0.10, \mathrm{p}<0.05$ for first wave; $\beta=0.17, \mathrm{p}<0.10$ for Later $)$, which supports Hypothesis 3 , that entrepreneurs with greater ESE invest a larger share of their financial portfolio in their ventures. Using the findings from the first wave regression, an increase in ESE from the $25^{\text {th }}$

\footnotetext{
${ }^{7}$ Since Household Wealth is the denominator in the Wealth Share variable, household wealth was not used as a control in the regression model for Wealth Share. Similarly, given strong correlation between household wealth and income, Household Income was also excluded from this regression. Importantly, the main findings from the Wealth Share model are unchanged if either or both of these controls are included.
} 
percentile to the $75^{\text {th }}$ percentile is associated with an increase in Wealth Share from 15.8 to 26.2 percent, an increase of approximately 65 percent.

\section{Insert Table 3 about here}

Columns 3 and 4 present the coefficients from the OLS regression models of Hours per Week and Hours per Week Later, respectively. The coefficient on ESE is positive and significant $(\beta=8.18, \mathrm{p}<0.001$ for first wave; $\beta=8.41, \mathrm{p}<0.05$ for Later). An increase in ESE from the $25^{\text {th }}$ percentile to the $75^{\text {th }}$ percentile is associated with an increase in Hours Per Week from 13.7 to 21.9 , an increase of approximately 60 percent. This supports Hypothesis 4, that entrepreneurs with greater ESE invest more personal labor in their ventures. For both Hours per Week and Wealth Share, the first wave specifications, due to their greater sample size, have lower standard errors and consequently exhibit greater statistical significance. However, the coefficients are similar in magnitude and sign, which suggests consistency across the results.

\section{Investment Risk}

We present the results of the investment risk models in Table 4 . We present the coefficients from the models of the Bitler et al. (2005) risk measure, the Li et al. (2004) risk measure, and the industry death rate risk measure in columns 1, 2, and 3, respectively. Inconsistent with our hypothesis, ESE is not significant in any of the models of risk, aside from the marginally positive significance in the industry death rate model. Further, even the risk preference of the entrepreneur is not associated significantly with organizational risk. In economic terms, an increase in ESE (Risk Preference) from the $25^{\text {th }}$ percentile to the $75^{\text {th }}$ percentile is associated with in an increase in the expected industry death rate from 10.9 (11.3) to 12.3 (11.5) percent, an increase of approximately 12 (1.5) percent. 
Insert Table 4 about here

Columns 4 and 5 present the coefficients from the dichotomous risk measures based on whether the venture is high-tech and whether spending money on R\&D is a major priority, respectively. Again, we hypothesize that individuals with higher ESE will be more likely to be involved in ventures with more manager-based risk. However, ESE is not significant in either of these models, thereby failing to support Hypothesis 5. Again, risk preference is also not observed to be associated with venture risk.

\section{Industry Controls}

All the presented results are tabulated without industry controls. Industry differences may explain variation in several of the dependent variables examined in this study. For example, industry may influence venture scale given variations in viable or efficient scale of ventures across different industries (Bates, 1995; Cassar, 2006). Further, different industries, given their varying operating structures and risk, may have varying access to financial and other resources. Industry may also proxy for the difficulty associated with transforming startup activity into an operating business. However, there are also arguments against controlling for industry. Specifically, if individuals can choose their industry for venturing, these industry choices may be a function of intended scale, resource requirements and venturing difficulty. Consistent with the assumptions underlying the industry risk regressions in Table 4, ESE, risk preference, and other factors may influence industry choice, whereby entrepreneurs optimize on expected returns, risk preferences and non pecuniary factors. Therefore, the decision to control for industry effects depends on if the industry choice of the entrepreneur is assumed to be endogenous or exogenous. To examine the possibility that our ESE and risk preference findings are driven by industry 
differences we included 2-digit SIC code industry dummies for the Operating Entrepreneur, Wealth Share, and Hours per Month regressions. In unreported results, all our findings for ESE and risk preference are invariant to the inclusion or exclusion of industry controls.

\section{Path Analysis}

The results thus far suggest that ESE is associated several aspects of entrepreneurial investment. To explore potential direct and indirect influences of ESE on entrepreneurial investment, we estimated path models using maximum likelihood in AMOS 16.0. Based on the arguments put forward in the hypotheses section and extant theories on the effects of domainspecific self-efficacy, there is potential for ESE to affect entrepreneurial investment through its effects on goal setting, goal commitment, and risk perception. We operationalize goal setting through a latent variable with two indicators. The first indicator is the log of one plus the venture's expected sales in five years. The second indicator is the log of one plus the venture's expected number of full-time employees in five years. These indicators capture the projected scale or complexity of the venture, which proxy for the entrepreneur's goal setting through size intentions (Cassar, 2006). The risk perception variable is based on the question, "On a scale of zero to one hundred, what is the likelihood that this business will be operating five years from now, regardless of who owns and operates the firm?" To our knowledge, the PSED does not offer a variable that can be thought to proxy for goal commitment. Therefore this potential intermediating construct is left out of the path models. Its effects may, however, be reflected in significant coefficients on the direct paths from ESE to the dependent variables.

The paths examined are depicted in Figure 1. The path analyses are conducted with Operating Entrepreneur, Wealth Share, and Hours per Week as dependent variables. ${ }^{8}$ ESE can

\footnotetext{
${ }^{8}$ Because the moderating variables are venture-specific, they were not asked to the PSED control sample, so Nascent Entrepreneur cannot be used as a dependent variable.
} 
affect each dependent variable directly, or through its effects on risk perception and goal setting. More complicated path models that included the controls used in the OLS specifications were also analyzed for each dependent variable. However, we only report the simplified version, without controls, because the findings are similar.

Results are reported in Table 5. The model for Operational Entrepreneur has a good fit with the data $\left(\mathrm{X}^{2}[3]=6.258, \mathrm{CFI}=0.97, \mathrm{RMSEA}=0.29\right)$, as reported in column 1 . All of the paths are at least marginally statistically significant $(\mathrm{p}<0.10)$. Individuals who perceive their ventures as less risky are more likely to reach the operational stage. This significant positive effect is to be expected if individuals can to some degree predict venture outcomes. The path coefficient from venture scale to Operating Business is negative, suggesting that larger, more complex startups are less likely to become operating businesses. The total effect of ESE on Operating Entrepreneur is 0.125 , which is close to but slightly less than the direct effect, suggesting that the negative ESE-Scale-Operating Entrepreneur effect dominates the positive ESE-Risk Preference-Operating Entrepreneur effect. Alternative models were estimated with various combinations of paths 1, 4, and 5 (in Figure 1) constrained to zero (seven other models in total). Each of these models had a significantly worse fit ( $p<0.07$ for the best of the seven) than the full model in Figure 1.

The path results for Wealth Share are presented in Table 5, Column 2. The overall model has good fit statistics $\left(\mathrm{X}^{2}[3]=5.887, \mathrm{CFI}=0.97\right.$, RMSEA $\left.=0.28\right)$. However, only the coefficients on paths 1,2 , and 3 are significant ( $\mathrm{p}<0.05,0.001$, and 0.01 , respectively). The coefficients on paths 4 and 5 are not statistically significant. Constraining these path coefficients to zero did not significantly affect model fit $\left(X^{2}[2]=0.959, p=0.62\right)$, suggesting that only the direct path is significant. 
The main path model estimated for Hours per Week was inadmissible, because the variance on the error term related to 5-year ahead sales projections was estimated to be negative, and negative variances are impossible. A specification search was performed to find the bestperforming admissible model, allowing combinations of the coefficients on paths 1,4 and 5 to be constrained to zero. Eight models were compared. In addition to the model in which the three path coefficients were unconstrained, the model constraining only the coefficient on path 5 was also inadmissible. The remaining six models examined were admissible. Of admissible models, the model with only the direct effect (path 1) coefficient unconstrained had the lowest RMSEA and $\mathrm{C} / \mathrm{df}(0.046$ and $\mathrm{C} / \mathrm{df}=3.617$, respectively). However, statistics are mixed on whether this model has a good fit with the data $\left(\mathrm{X}^{2}[5]=18.087, \mathrm{p}=0.003, \mathrm{CFI}=0.898, \mathrm{RMSEA}=0.046\right)$, so the coefficients are not tabulated in Table 5, as the direct effect is already estimated in the main results shown in Table 3.

It is somewhat surprising that Wealth Share and Hours per Week may not be affected by risk perception and venture scale. Based on the theories concerning self-efficacy, the direct path may represent goal commitment or aspects of goal setting and risk perception not captured by our empirical proxies. Further, path analyses were conducted with each of the five risk measures as dependent variables, but the results were qualitatively very similar to the results from the OLS analysis, in that the direct and indirect paths from ESE to risk measures were insignificant. Therefore these results are not reported.

\section{Changes in ESE from Entrepreneurial Experiences}

To examine the importance of controlling for changes in ESE as a result of feedback from entrepreneurial experiences, consistent with Zhao et al. (2005), we performed a regression modeling ESE after the entrepreneurial activity (Later ESE) as a linear function of the initial 
ESE and whether the individual achieved an operating business from their nascent activity (Operating Entrepreneur). Specifically, Later ESE was taken from the latest mail questionnaire from the PSED, which represented when the individual quit the venture, the venture failed, the venture became an operational business, or the latest mail questionnaire while the venture was still in the start-up phase. For the model estimated on the 408 individuals that have non-missing responses for ESE, Operating Entrepreneur and Later ESE, we observe the coefficient on Operating Entrepreneur is positive and significant $(\beta=0.12, \mathrm{p}<0.04)$ consistent with positive (negative) feedback from entrepreneurial experiences being associated with relative increase (decrease) in individual's ESE. This highlights the importance of controlling for feedback effects when making causal inferences on ESE and entrepreneurial behavior. As expected, we also find initial ESE to be positive and significantly associated with later $\operatorname{ESE}(\beta=0.40, \mathrm{p}<0.001)$.

\section{Discussion}

Implications for Theory and Practice

This study contributes to the literature by conducting a novel investigation of the role of self-efficacy on several dimensions of entrepreneurial investment choice. While research in entrepreneurial investment has focused on either the entry decision or financial capital allocation, our results show that self-efficacy is a significant factor in decisions related to entrepreneurial entry, capital sources of entrepreneurial ventures, and personal labor allocation. Decomposing entrepreneurial entry into two sub-decisions: nascent entrepreneurship and operational entrepreneurship, we find that ESE is a significant driver of the decision both to invest in discovering an entrepreneurial opportunity and to exploit an entrepreneurial opportunity. Therefore, our evidence is consistent with the prevalence of ESE amongst existing entrepreneurs 
being driven by both a propensity to enter entrepreneurship and the effect of ESE on the transition from nascent to operational entrepreneurship.

Prior evidence showing higher ESE in founder-managers than non-founders makes it difficult to determine the true causal affect on ESE on entrepreneurial behavior, as ESE is influenced by feedback from entrepreneurial experiences. Therefore, individuals who have successfully founded new businesses may experience an increase in ESE, due to positive feedback, relative to individuals who were unsuccessful in venturing who experience negative feedback. Consistent with these conjectures, we find that individuals who achieve an operating business from their nascent activity have an increase in their ESE in future surveys relative to those entrepreneurs who did not. This observed ESE feedback effect highlights the importance of using a longitudinal research design to investigate causal associations on ESE on entrepreneurial behavior. Overall, by showing that ESE causally affects entry and investment at different stages of the entrepreneurial process, we contribute to the understanding of entrepreneurial entry and investment, and consequently, to the organizational creation literature.

Beyond the entrepreneurial entry decisions, we further examined the investment of financial and human resources in entrepreneurship. We found that individuals with high selfefficacy devoted a greater proportion of their wealth and more time per week to venturing activities. We argued that entrepreneurs with greater ESE, having greater belief in their entrepreneurial talents, undertake more aggressive actions across both of these dimensions of entrepreneurial investment. Overall, our findings expand understanding of entrepreneurial investment decisions to a wide range of choices affecting both operational and financial aspects of new ventures. The breadth of results suggests that individuals with high self-efficacy generally invest more aggressively in the highly uncertain entrepreneurial setting. Therefore, we contribute 
to the literature by providing evidence of links between beliefs about oneself and economic decisions made under uncertainty. Further, we contribute to literature on entrepreneurial investment by considering finer conceptualizations of investment and of entrepreneurship.

Research has shown the consequences of firms' aggressive investment using their expenditures in R\&D and deployment of financing. While contingent on the firm's environment, several studies have shown better financial performance for those firms that undertake greater commitment in the investment and exploitation of resources to achieve a competitive advantage (Feeser \& Willard, 1990; Fombrun \& Ginsberg, 1990; Grinyer, McKiernan, \& Yasai-Ardekani, 1988; Weinzimmer, Bond III, Houston, \& Nystrom, 2003). ${ }^{9}$ Our study differs from this research in that we consider individuals', rather than firms', investment choices. Notably, readers should be careful in interpreting the achievement of an operating business by individuals with greater self-efficacy as a successful outcome. For example, greater investment of effort and financial capital should result in a greater likelihood of achieving a viable operating business and greater revenues and profits. However, whether this aggressive investment is a good outcome is dependent on the financial returns and non-pecuniary benefits being commensurate with the opportunity costs of the effort and capital investment made, which is not observed in this study. More generally, we contribute to the broader literature on investment aggressiveness by considering an individual's investment aggressiveness rather than the firm's investment behavior.

Our findings have implications for practitioners operating in uncertain settings. Entrepreneurs and managers can benefit from understanding that ESE leads to more aggressive decisions in entrepreneurial settings. In situations where aggressive investment decisions may be

\footnotetext{
${ }^{9}$ For a theoretical counter argument see McGrath's (1999) discussion of real options.
} 
highly detrimental, such as when industry sales are declining (Romanelli, 1989), entrepreneurs can use formal decision-making procedures or teams to more closely monitor and control the effects of an individual's self-efficacy (Schweiger, Sandberg, \& Ragan, 1986). Alternatively, entrepreneurs can allow self-efficacy to flourish in situations where investment aggressiveness is considered more beneficial, such as when it is necessary to gain a first-mover advantage or avoid laggard disadvantages (Agarwal \& Gort, 2001; Lieberman \& Montgomery, 1988; Narasimhan \& Zhang, 2000). This may be particularly relevant for firms that engage in or encourage corporate entrepreneurship.

While distinct from other psychological constructs, we would expect that the observed associations between ESE and aggressive investment may also exist between other psychologybased measures of self-belief and aggressive investment. Specifically, locus of control, selfesteem, core self-evaluation, and overconfidence, which all represent various beliefs about one's abilities, attitudes, or outcomes of actions, may positively influence the extent to which individuals invest in entrepreneurial activity. Such beliefs may also affect the degree to which entrepreneurial investments are perceived to be sunk and the extent to which individuals escalate their commitment of investment in venturing when the objective likelihood of success is low. For example, there is some evidence suggesting that self-efficacy and confidence is associated with greater commitment of resources in settings that are highly risky or highly likely to be a losing course of action (McCarthy et al., 1993; Whyte, Saks, \& Hook, 1997). While we show greater self-efficacy is associated with greater entrepreneurial investment, given our research design, we cannot determine whether this is also an inappropriate over-commitment of resources to the startup activity. For example, we observed that self-efficacy is associated both with greater investment and greater likelihood of achieving an operating business from nascent activity. 
Future research could investigate how various beliefs about oneself are associated with a broad range of entrepreneurial activities.

\section{Limitations and Future Research}

Interestingly, we did not observe self-efficacy or risk preference affecting entrepreneurial investment risk. We posited that individuals with high self-efficacy and higher risk preferences would make riskier entrepreneurial investments, which would be reflected in their industry choice and the characteristics of their investment. A possible explanation for this is that selfefficacy and risk preference may have a second order effect on industry or venture type choice after other influences, such as human capital and specific knowledge, or intrinsic factors. For example, a lack of specific knowledge or prohibitively high switching costs related to obtaining specific knowledge may result in an inability to earn sufficient returns in other industries. If human capital concerns result in limited movement between industries or types of ventures based on R\&D intensity or extent of technology, this would inhibit industry movement based on other concerns, such as risk preference. Consistent with these conjectures, we observe that 89 percent of the sample of nascent entrepreneurs reported having at least one year of work experience in the industry in which their new venture would compete.

Surprisingly, we are unaware of empirical research that investigates what factors influence entrepreneurs' industry choice beyond evidence that previous industry experience is important. Empirical investigation of what factors drive the industry choices of entrepreneurs would enhance understanding of entrepreneurial entry. Additionally, investigating entrepreneurial risk dimensions beyond those directly related to industry may provide important insight into the determinants of entrepreneurial investment riskiness. 
We focused on the choices of individuals in the highly uncertain setting of organization creation, as uncertainty tends to exacerbate the effects of self-efficacy. In other, less uncertain settings, these effects may be weaker. Therefore, the ability to generalize our findings across all investment choice settings may be limited. For example, personal beliefs or cognitive biases may have a weaker effect on decision makers and their investment choices in existing firms or in later stages of entrepreneurship, as they generally face less uncertainty. Additionally, the link between self-efficacy and behavior may be weakened by organizational factors, such as formal decisionmaking processes designed to dampen the influence of individual preference. Exploring the effects of personal beliefs or cognitive biases on decisions made by existing entrepreneurs and corporate managers across many investment dimensions would provide bounds on the theories and outcomes investigated in this study.

Although we examined a richer set of entrepreneur investment choices than previously researched, there is substantial opportunity to explore further heterogeneity of investment in this setting. For example, while we identified the total financial and personal labor invested in the venture, we were unable to determine the specific investment amounts devoted to each resource and activity in the venturing process. Understanding if there are systematic differences in successful and unsuccessful ventures and what traits, characteristics, or beliefs explain variation in investment choices is an important, yet relatively unexplored area of research.

\section{Conclusion}

We find that individuals' ESE, a domain-specific self-efficacy, is associated with more aggressive deployment of resources to their new ventures. In particular, we observe that the likelihood of nascent entry, the likelihood of achieving an operating business from their nascent activity, the amount of financial capital and the amount of personal effort is greater for 
individuals with higher ESE. We find that the relationship between ESE and entrepreneurial investment is both statistically and economic significant. We contribute to existing research by utilizing a longitudinal design based on a representative sample to document a causal relationship between ESE and several dimensions of entrepreneurial investment. However, unlike research beyond the entrepreneurial domain we find little evidence of an association between ESE and risk in entrepreneurial investment in our sample. We suggest further research on the relationship between the beliefs of entrepreneurs and their risk choices and actions is merited.

\section{Acknowledgements}

The authors would like to thank seminar participants at Wharton Research Scholars and 2007 Babson College Entrepreneurship Research Conference in Madrid, Katherine Klein and Cathy Schrand for their helpful input. Gavin Cassar would also like to thank the Sol C. Snider Entrepreneurial Research Center and Wharton Entrepreneurial Programs for their financial support. This research would not be possible without the efforts of the Entrepreneurial Research Consortium. 


\section{References}

Agarwal R, Gort M. 2001. First-Mover Advantage and the Speed of Competitive Entry, 18871986. Journal of Law and Economics 44(1): 161-177

Amit R, Livnat J. 1988. Diversification and the risk-return trade-off. Academy of Management Journal 31(1): 154-166

Bandura A. 1997. Self-Efficacy in Changing Societies. Cambridge University Press

Bandura A. 2001. Social Cognitive Theory: An Agentic Perspective. Annual Review of Psychology 52(1): 1-26

Bandura A, Cervone D. 1986. Differential engagement of self-reactive mechanisms governing the motivational effects of goal systems. Organizational Behavior and Human Decision Processes 38(1): 92-113

Bates T. 1995. Self-employment entry across industry groups. Journal of Business Venturing 10(2): $143-156$

Baum JR, Locke EA. 2004. The relationship of entrepreneurial traits, skill, and motivation to subsequent venture growth. J Appl Psychol 89(4): 587-598

Baum JR, Locke EA, Smith KG. 2001. A Multidimensional Model of Venture Growth. The Academy of Management Journal 44(2): 292-303 
Betz NE, Hackett G. 1983. The Relationship of Mathematics Self-Efficacy Expectations to the Selection of Science-Based College Majors. Journal of Vocational Behavior 23(3): 329-345

Bitler MP, Moskowitz TJ, Vissing-Jorgensen A. 2005. Testing Agency Theory with Entrepreneur Effort and Wealth. The Journal of Finance 60(2): 539-576

Bruderl J, Preisendorfer P, Ziegler R. 1992. Survival Chances of Newly Founded Business Organizations. American Sociological Review 57(2): 227-242

Busenitz LW, Barney JB. 1997. Differences between entrepreneurs and managers in large organizations: Biases and heuristics in strategic decision-making. Journal of Business Venturing 12(1): 9-30

Camerer C, Lovallo D. 1999. Overconfidence and Excess Entry: An Experimental Approach. The American Economic Review 89(1): 306-318

Carpenter MA, Pollock TG, Leary MM. 2003. Testing a model of reasoned risk-taking: governance, the experience of principals and agents, and global strategy in high-technology IPO firms. Strategic Management Journal 24(9): 803-820

Carter NM, Gartner WB, Shaver KG, Gatewood EJ. 2003. The career reasons of nascent entrepreneurs. Journal of Business Venturing 18(1): 13-39 
Cassar G. 2006. Entrepreneur opportunity costs and intended venture growth. Journal of Business Venturing 21(5): 610-632

Cassar G. 2007. Money, money, money? A longitudinal investigation of entrepreneur career reasons, growth preferences and achieved growth. Entrepreneurship \& Regional Development 19(1): $89-107$

Chen CC, Greene PG, Crick A. 1998. Does entrepreneurial self-efficacy distinguish entrepreneurs from managers? Journal of Business Venturing 13(4): 295-316

Clark NM, Dodge JA. 1999. Exploring Self-Efficacy as a Predictor of Disease Management. Health Education \& Behavior 26(1): 72

Coles JL, Daniel ND, Naveen L. 2006. Managerial incentives and risk-taking. Journal of Financial Economics 79(2): 431-468

Cooper AC, Woo CY, Dunkelberg WC. 1989. Entrepreneurship and the initial size of firms. Journal of Business Venturing 4(5): 317-332

Davidsson P, Honig B. 2003. The role of social and human capital among nascent entrepreneurs. Journal of Business Venturing 18(3): 301-331

Eden D, Aviram A. 1993. Self-efficacy training to speed reemployment: helping people to help themselves. Journal of Applied Psychology 78(3): 352-360 
Feeser HR, Willard GE. 1990. Founding strategy and performance: A comparison of high and low growth high tech firms. Strategic Management Journal 11(2)

Fombrun CJ, Ginsberg A. 1990. Shifting gears: Enabling change in corporate aggressiveness. Strategic Management Journal 11(4)

Forbes DP. 2005a. Are some entrepreneurs more overconfident than others? Journal of Business Venturing 20(5): 623-640

Forbes DP. 2005b. The effects of strategic decision making on entrepreneurial self-efficacy. Entrepreneurship Theory and Practice 29(5): 599-626

Gartner WB. 2004. Handbook of Entrepreneurial Dynamics: The Process of Business Creation. Sage Publications Inc

Gimeno J, Folta TB, Cooper AC, Woo CY. 1997. Survival of the Fittest? Entrepreneurial Human Capital and the Persistence of Underperforming Firms. Administrative Science Quarterly 42(4)

Gist ME. 1987. Self-Efficacy: Implications for Organizational Behavior and Human Resource Management. The Academy of Management Review 12(3): 472-485

Gist ME, Mitchell TR. 1992. Self-Efficacy: A Theoretical Analysis of Its Determinants and Malleability. The Academy of Management Review 17(2): 183-211 
Grinyer PH, McKiernan P, Yasai-Ardekani M. 1988. Market, organizational and managerial correlates of economic performance in the UK electrical engineering industry. Strategic Management Journal 9(4)

Hackett G. 1985. Role of Mathematics Self-Efficacy in the Choice of Math-Related Majors of College Women and Men: A Path Analysis. Journal of Counseling Psychology 32(1): 47-56

Hackett G. 1997. Self-efficacy in career choice and development. In A Bandura (Ed.), Selfefficacy in changing societies: 232. Cambridge University Press

Hackett G, Betz NE. 1989. An Exploration of the Mathematics Self-Efficacy/Mathematics Performance Correspondence. Journal for Research in Mathematics Education 20(3): 261-273

Hayward MLA, Shepherd DA, Griffin D. 2006. A Hubris Theory of Entrepreneurship. Management Science 52(2): 160-172

Hmieleski KM, Baron RA. 2008. When does Entrepreneurial Self-Efficacy Enhance Versus Reduce Firm Performance? Strategic Entrepreneurship Journal 2: 57-72

Holtz-Eakin D, Joulfaian D, Rosen HS. 1994. Sticking it Out: Entrepreneurial Survival and Liquidity Constraints. The Journal of Political Economy 102(1): 53-75

Hurst E, Lusardi A. 2004. Liquidity constraints, wealth accumulation and entrepreneurship. Journal of Political Economy 112(2): 319-347 
Jackson DN. 1994. Jackson Personality Inventory: Revised Manual. Sigma Assessment Systems

Judge TA, Bono JE. 2001. Relationship of core self-evaluations traits-self-esteem, generalized $\underline{\text { self-efficacy, locus of control, and emotional stability — with job satisfaction and job }}$ performance: A meta-analysis. Journal of Applied Psychology 86(1): 80-92

Judge TA, Bono JE, Thoresen CJ. 2003. The Core Self-Evaluations Scale: Development of a Measure. Personnel Psychology 56(2): 303-332

Kallman J. 2007. Measuring Risk. Risk Management 54(7): 2

Kamien M, Schwartz NL. 1971. Expenditure Patterns for Risky R\&D Projects. Journal of Applied Probability 8(1): 60-73

Kim PH, Aldrich HE, Keister LA. 2006. Access (Not) Denied: The Impact of Financial, Human, and Cultural Capital on Entrepreneurial Entryin the United States. Small Business Economics 27(1): 5-22

Kirzner IM. 1978. Competition and Entrepreneurship. University Of Chicago Press

Knight FH. 1921. Risk, Uncertainty and Profit. Houghton Mifflin Company

Kothari SP, Laguerre TE, Leone AJ. 2002. Capitalization versus Expensing: Evidence on the Uncertainty of Future Earnings from Capital Expenditures versus R\&D Outlays. Review of Accounting Studies 7(4): 355-382 
Krueger N, Dickson PR. 1994. How believing in ourselves increases risk taking: Perceived selfefficacy and opportunity recognition. Decision Sciences 25(3): 385-400

Lent RW, Hackett G. 1987. Career Self-Efficacy: Empirical Status and Future Directions. Journal of Vocational Behavior 30(3): 347-382

Levenson H. 1973. Multidimensional locus of control in psychiatric patients. J Consult Clin Psychol 41(3): 397-404

Li K, Morck R, Yang F, Yeung B. 2004. Firm-specific variation and openness in emerging markets. Review of Economics and Statistics 86(3): 658-669

Lichtenstein S, Fischhoff B. 1977. Do those who know more also know more about how much they know. Organizational Behavior and Human Performance 20(2): 159-183

Lieberman MB, Montgomery DB. 1988. First-mover advantages. Strategic Management Journal 9: $41-58$

Locke E, Frederick E, Lee C, Bobko P. 1984. Effects of self-efficacy, goal-setting and performance. Journal of Applied Psychology 69: 241-251

Loury GC. 1979. Market Structure and Innovation. Quarterly Journal of Economics 93(3): 395410 
Lowe RA, Ziedonis AA. 2006. Overoptimism and the Performance of Entrepreneurial Firms. Management Science 52(2): 173-186

Luszczynska A, Gutiérrez-Doña B, Schwarzer R. 2005. General self-efficacy in various domains of human functioning: Evidence from five countries. International Journal of Psychology 40(2): 80-89

MacCrimmon KR, Wehrung DA. 1990. Characteristics of Risk Taking Executives. Management Science 36(4): 422-435

Mahmood T. 2000. Survival of Newly Founded Businesses: A Log-Logistic Model Approach. Small Business Economics 14(3): 223-237

March JG, Shapira Z. 1987. Managerial Perspectives on Risk and Risk Taking. Management Science 33(11): 1404-1418

McAuley E, Courneya KS, Rudolph DL, Lox CL. 1994. Enhancing exercise adherence in middle-aged males and females. Prev Med 23(4): 498-506

McCarthy AM, Schoorman FD, Cooper AC. 1993. Reinvestment decisions by entrepreneurs: rational decision-making or escalation of commitment. Journal of Business Venturing 8(1): 9-24

McMullen JS, Shepherd DA. 2006. Entrepreneurial Action and the Role of Uncertainty in the Theory of the Entrepreneur. Academy of Management Journal 31: 132-152 
Miller KD, Bromiley P. 1990. Strategic Risk and Corporate Performance: An Analysis of Alternative Risk Measures. The Academy of Management Journal 33(4): 756-779

Moskowitz TJ, Vissing-Jorgensen A. 2002. The Returns to Entrepreneurial Investment: A Private Equity Premium Puzzle? The American Economic Review 92(4): 745-778

Narasimhan C, Zhang ZJ. 2000. Market Entry Strategy under Firm Heterogeneity and Asymmetric Payoffs. Marketing Science 19(4): 313-327

Parker SC, Belghitar Y. 2006. What Happens to Nascent Entrepreneurs? An Econometric Analysis of the PSED. Small Business Economics 27(1): 81-101

Podsakoff PM, MacKenzie SB, Lee JY, Podsakoff NP. 2003. Common method biases in behavioral research: A critical review of the literature and recommended remedies. Journal of Applied Psychology 88(5): 879-903

Puri M, Robinson DT. 2007. Optimism and economic choice. Journal of Financial Economics 86(1): 71-99

Romanelli E. 1989. Environments and strategies of organization start-up: Effects on early survival. Administrative Science Quarterly: 369-387

Rosenberg M. 1965. Society and the Adolescent Self-Image. Princeton University Press: Princeton, New Jersey 
Rotter JB. 1966. Generalized expectancies for internal versus external control of reinforcement. Psychol Monogr 80(1): 1-28

Scheier MF, Carver CS, Bridges MW. 1994. Distinguishing optimism from neuroticism (and trait anxiety, self-mastery, and self-esteem): a reevaluation of the Life Orientation Test. J Pers Soc Psychol 67(6): 1063-1078

$\underline{\text { Scherer FM. 1967. Research and development resource allocation under rivalry. Quarterly }}$ Journal of Economics 81(3): 359-394

Schumpeter JA. 1934. The Theory of Economic Development, translated by Redvers Opie. Harvard: Economic Studies $\mathbf{4 6}$

Schweiger DM, Sandberg WR, Ragan JW. 1986. Group Approaches for Improving Strategic Decision Making: A Comparative Analysis of Dialectical Inquiry, Devil's Advocacy, and Consensus. The Academy of Management Journal 29(1): 51-71

Shepherd DA, McMullen JS, Jennings PD. 2007. The formation of opportunity beliefs: overcoming ignorance and reducing doubt. Strategic Entrepreneurship Journal 1: 75-95

Sherer M, Maddux JE, Mercandante B, Prentice-Dunn S, Jacobs B, Rogers RW. 1982. The selfefficacy scale: Construction and validation. Psychological reports 51(2): 663-671 
Simon M, Houghton SM. 2003. The relationship between overconfidence and the introduction of risky products: evidence from a field study. Academy of Management Journal 46(2): 139-149

$\underline{\text { Simon M, Houghton SM, Savelli S. 2003. Out of the frying pan...? Why small business }}$ managers introduce high-risk products. Journal of Business Venturing 18(3): 419-440

Singh JV. 1986. Performance, slack, and risk taking in organizational decision making. Academy of Management Journal 29(3): 562-585

Stajkovic AD, Luthans F. 1998. Self-efficacy and work-related performance: A meta-analysis. Psychological Bulletin 124(2): 240-261

Weinzimmer LG, Bond III EU, Houston MB, Nystrom PC. 2003. Relating marketing expertise on the top management team and strategic market aggressiveness to financial performance and shareholder value. Journal of Strategic Marketing 11(2): 27

White RE, Thornhill S, Hampson E. 2006. Entrepreneurs and evolutionary biology: The relationship between testosterone and new venture creation. Organizational Behavior and Human Decision Processes 100(1): 21-34

Whyte G, Saks AM, Hook S. 1997. When success breeds failure: The role of self-efficacy in escalating commitment to a losing course of action. Journal of Organizational Behavior 18(5) 
Wood R, Bandura A. 1989a. Impact of conceptions ofability on self-regulatory mechanisms and complex decision making. Journal of personality and social psychology 56(3.407-415)

Wood R, Bandura A. 1989b. Social Cognitive Theory of Organizational Management. The Academy of Management Review 14(3): 361-384

Wood R, Bandura A, Bailey T. 1990. Mechanisms governing organizational performance in complex decision-making environments. Organizational Behavior and Human Decision

Processes 46(2): 181-201

Wulfert E, Wan CK. 1993. Condom use: a self-efficacy model. Health Psychol 12(5): 346-353

Zhao H, Seibert SE, Hills GE. 2005. The mediating role of self-efficacy in the development of entrepreneurial intentions. Journal of Applied Psychology 90(6): 1265-1272 
TABLE 1

Descriptive Statistics and Correlations ${ }^{\mathrm{a}}$

\begin{tabular}{|c|c|c|c|c|c|c|c|c|c|c|c|c|c|c|}
\hline Variables & Mean & $\begin{array}{l}\text { Std. } \\
\text { Dev. }\end{array}$ & $\mathbf{n}$ & 1 & 2 & 3 & 4 & 5 & 7 & 8 & 9 & 10 & 11 & 12 \\
\hline 1. ESE & 4.13 & 0.72 & 888 & & & & & & & & & & & \\
\hline 2. Risk Pref. & 0.31 & 0.21 & 877 & 0.20 & & & & & & & & & & \\
\hline 3. Nascent Entp. & 0.66 & 0.47 & 1263 & 0.29 & 0.07 & & & & & & & & & \\
\hline 4. Operating Entp. & 0.44 & 0.50 & 606 & 0.16 & -0.01 & - & & & & & & & & \\
\hline 5. Wealth Share & 0.19 & 0.49 & 661 & 0.13 & 0.09 & - & 0.08 & & & & & & & \\
\hline 6. Hours/Week & 20.34 & 21.13 & 399 & 0.26 & 0.23 & - & 0.25 & 0.12 & & & & & & \\
\hline 7. Risk (Bitler) & 0.84 & 0.20 & 776 & 0.02 & 0.03 & -0.04 & 0.11 & 0.03 & -0.01 & & & & & \\
\hline 8. Risk (Li et al) & 0.30 & 0.13 & 683 & 0.03 & 0.04 & 0.25 & -0.04 & -0.05 & -0.16 & 0.14 & & & & \\
\hline 9. SIC Death Rate & 0.11 & 0.09 & 450 & 0.09 & 0.06 & 0.23 & 0.39 & -0.11 & 0.06 & - & 0.29 & & & \\
\hline 10. $\mathrm{R} \& \mathrm{D}$ & 0.31 & 0.46 & 792 & 0.06 & 0.07 & - & -0.06 & 0.06 & 0.05 & -0.02 & 0.07 & -0.20 & & \\
\hline 11. High Tech & 0.36 & 0.48 & 796 & -0.04 & 0.11 & - & 0.06 & 0.06 & -0.01 & 0.15 & 0.32 & -0.11 & 0.20 & \\
\hline 12. College & 0.26 & 0.44 & 1248 & 0.00 & 0.07 & 0.09 & 0.06 & -0.04 & -0.01 & 0.00 & 0.06 & 0.09 & -0.04 & 0.01 \\
\hline 13. Mgr. Exp & 1.72 & 1.05 & 1215 & 0.13 & 0.08 & 0.13 & 0.08 & 0.01 & 0.10 & 0.00 & 0.00 & 0.11 & 0.00 & -0.04 \\
\hline 14. HH Income & 10.61 & 1.04 & 1122 & 0.04 & 0.05 & 0.10 & 0.14 & -0.12 & 0.09 & 0.03 & 0.06 & 0.02 & -0.06 & -0.04 \\
\hline 15. HH Wealth & 11.14 & 1.66 & 1058 & 0.00 & 0.03 & 0.07 & 0.14 & -0.35 & 0.13 & -0.02 & 0.04 & 0.06 & -0.02 & -0.02 \\
\hline 16. Parents Entp. & 0.48 & 0.50 & 1233 & 0.06 & -0.02 & 0.09 & -0.01 & -0.01 & 0.03 & -0.04 & -0.03 & 0.04 & -0.02 & -0.02 \\
\hline 17. Age & 40.01 & 12.19 & 1223 & -0.04 & -0.03 & -0.03 & 0.07 & -0.04 & 0.01 & -0.10 & -0.08 & 0.02 & -0.05 & -0.05 \\
\hline 18. Female & 0.51 & 0.50 & 1260 & -0.07 & -0.22 & -0.07 & 0.00 & -0.08 & -0.10 & -0.07 & -0.06 & -0.10 & -0.05 & -0.19 \\
\hline 19. Married & 0.52 & 0.50 & 1245 & 0.06 & -0.06 & 0.07 & 0.10 & -0.08 & 0.03 & 0.02 & 0.04 & 0.10 & -0.18 & -0.14 \\
\hline 20. In Development & 0.21 & 0.41 & 813 & 0.08 & 0.04 & - & -0.11 & 0.00 & -0.11 & 0.03 & 0.06 & -0.15 & 0.15 & 0.04 \\
\hline 21. In Testing & 0.19 & 0.39 & 813 & 0.08 & 0.02 & - & -0.04 & 0.09 & 0.08 & -0.05 & -0.02 & -0.10 & 0.02 & 0.02 \\
\hline 22. Completed & 0.43 & 0.50 & 813 & -0.07 & -0.02 & - & 0.22 & -0.02 & 0.12 & -0.01 & -0.01 & 0.10 & -0.15 & -0.07 \\
\hline 23. South & 0.37 & 0.48 & 1263 & 0.04 & 0.04 & -0.02 & 0.01 & 0.08 & 0.04 & 0.01 & -0.04 & -0.01 & 0.05 & 0.03 \\
\hline 24. Midwest & 0.21 & 0.41 & 1263 & -0.03 & -0.05 & 0.00 & 0.02 & 0.00 & -0.08 & 0.02 & -0.07 & 0.06 & -0.03 & -0.07 \\
\hline 25. West & 0.22 & 0.42 & 1263 & 0.02 & 0.01 & 0.03 & -0.05 & -0.04 & 0.05 & 0.00 & $\mathbf{0 . 0 8}$ & -0.06 & 0.03 & 0.05 \\
\hline
\end{tabular}


TABLE 1 (cont.)

Descriptive Statistics and Correlations

\begin{tabular}{|c|c|c|c|c|c|c|c|c|c|c|c|c|c|}
\hline Variables & 13 & 14 & 15 & 16 & 17 & 18 & 19 & 20 & 21 & 22 & 23 & 24 & 25 \\
\hline 14. Mgr. Exp & 0.12 & & & & & & & & & & & & \\
\hline 15. HH Income & 0.09 & 0.14 & & & & & & & & & & & \\
\hline 16. HH Wealth & 0.12 & 0.27 & 0.42 & & & & & & & & & & \\
\hline 17. Parents Entp. & 0.10 & 0.09 & 0.06 & 0.08 & & & & & & & & & \\
\hline 18. Age & 0.03 & 0.45 & -0.01 & 0.23 & 0.01 & & & & & & & & \\
\hline 19. Female & -0.01 & -0.10 & -0.08 & -0.06 & 0.04 & 0.05 & & & & & & & \\
\hline 20. Married & 0.03 & 0.19 & 0.26 & 0.24 & 0.04 & 0.15 & -0.03 & & & & & & \\
\hline 21. In Development & -0.05 & 0.01 & 0.02 & -0.05 & 0.00 & -0.08 & -0.04 & -0.08 & & & & & \\
\hline 22. In Testing & 0.00 & 0.09 & -0.03 & -0.02 & 0.07 & 0.04 & -0.07 & -0.01 & -0.25 & & & & \\
\hline 23. Completed & 0.10 & 0.02 & 0.08 & 0.10 & 0.04 & 0.09 & 0.05 & 0.16 & -0.45 & -0.42 & & & \\
\hline 24. South & 0.02 & 0.00 & -0.03 & -0.04 & -0.06 & -0.05 & -0.04 & 0.04 & 0.01 & 0.04 & -0.05 & & \\
\hline 25. Midwest & -0.02 & -0.03 & -0.02 & 0.01 & 0.02 & 0.05 & 0.03 & -0.01 & -0.04 & 0.01 & 0.02 & -0.40 & \\
\hline 26. West & -0.04 & 0.01 & 0.04 & 0.04 & 0.06 & 0.02 & 0.00 & 0.03 & 0.00 & 0.04 & -0.01 & -0.41 & -0.28 \\
\hline
\end{tabular}

${ }^{\mathrm{a}}$ Correlation coefficients in bold are significant at the $5 \%$ level (two-tailed tests). 
TABLE 2

Results of Logistic Regression of Entrepreneurial Entry ${ }^{\text {a }}$

\begin{tabular}{|c|c|c|c|c|c|c|c|c|}
\hline \multirow[b]{2}{*}{ Variables } & \multicolumn{4}{|c|}{ Nascent Entrepreneur } & \multicolumn{4}{|c|}{ Operating Entrepreneur } \\
\hline & Model & & Model & & Model & & Model 6 & \\
\hline ESE & $0.87 * * *$ & $(0.11)$ & $0.86 * * *$ & $(0.13)$ & $0.66 * * *$ & $(0.17)$ & $0.80 * * *$ & $(0.21)$ \\
\hline Risk Preference & 0.25 & $(0.37)$ & 0.60 & $(0.45)$ & -0.19 & $(0.46)$ & -0.33 & $(0.58)$ \\
\hline College & & & $0.36 \dagger$ & $(0.20)$ & & & -0.20 & $(0.26)$ \\
\hline Mgr. Exp. & & & $0.25 * *$ & $(0.10)$ & & & 0.05 & $(0.13)$ \\
\hline HH Income & & & -0.04 & $(0.11)$ & & & $0.34 \dagger$ & $(0.19)$ \\
\hline HH Wealth & & & 0.02 & $(0.07)$ & & & $0.23 *$ & $(0.09)$ \\
\hline Parents Entp. & & & -0.09 & $(0.18)$ & & & -0.10 & $(0.24)$ \\
\hline Age & & & $-0.02 *$ & $(0.01)$ & & & 0.00 & $(0.01)$ \\
\hline Female & & & 0.02 & $(0.18)$ & & & 0.06 & $(0.25)$ \\
\hline Married & & & 0.24 & $(0.19)$ & & & -0.11 & $(0.26)$ \\
\hline In Development & & & & & & & -0.22 & $(0.45)$ \\
\hline In Testing & & & & & & & 0.12 & $(0.42)$ \\
\hline Completed & & & & & & & $0.90 *$ & $(0.37)$ \\
\hline South & & & -0.11 & $(0.24)$ & & & -0.04 & $(0.34)$ \\
\hline Midwest & & & 0.21 & $(0.27)$ & & & 0.24 & $(0.36)$ \\
\hline West & & & 0.23 & $(0.28)$ & & & 0.01 & $(0.38)$ \\
\hline Intercept & $-2.24 * * *$ & $(0.35)$ & -1.99 & $(1.27)$ & -2.25 & $(0.60)$ & $-9.29 * * *$ & (2.09) \\
\hline -2Log Likelihood & 1064.46 & & 779.74 & & 589.72 & & 426.57 & \\
\hline Model Chi-Square & $73.63 * * *$ & & $80.91 * * *$ & & $16.16^{* * *}$ & & $53.82 * * *$ & \\
\hline Pseudo- $\mathrm{R}^{2}$ & 0.08 & & 0.12 & & 0.04 & & 0.14 & \\
\hline $\mathrm{n}$ & 863 & & 660 & & 438 & & 347 & \\
\hline
\end{tabular}

${ }^{\mathrm{a}}$ Standard errors are reported in parentheses. $\dagger p<0.10 ; * p<0.05 ; * * p<0.01 ; * * * p<0.001$, two tailed tests. 
TABLE 3

Results of OLS Regressions on Financial and Human Resource Investment ${ }^{\text {a }}$

\begin{tabular}{|c|c|c|c|c|c|c|c|c|}
\hline \multirow[b]{2}{*}{ Variables } & \multicolumn{4}{|c|}{ Wealth Share } & \multicolumn{4}{|c|}{ Hours per Week } \\
\hline & \multicolumn{2}{|c|}{ First Wave } & \multicolumn{2}{|c|}{ Later } & \multicolumn{2}{|c|}{ First Wave } & \multicolumn{2}{|c|}{ Later } \\
\hline ESE & $0.10 *$ & $(0.04)$ & $0.17 \dagger$ & $(0.10)$ & $8.18 * * *$ & $(2.04)$ & $8.41^{*}$ & $(3.55)$ \\
\hline Risk Preference & 0.16 & $(0.13)$ & 0.42 & $(0.27)$ & $21.55^{* * *}$ & $(6.17)$ & 7.52 & $(9.54)$ \\
\hline College & -0.05 & $(0.06)$ & -0.003 & $(0.13)$ & 0.78 & $(2.81)$ & 1.63 & $(4.53)$ \\
\hline Mgr. Exp. & 0.004 & $(0.03)$ & -0.03 & $(0.06)$ & 1.10 & $(1.44)$ & -0.41 & (2.14) \\
\hline HH Income & & & & & 1.17 & (1.39) & -3.13 & (3.23) \\
\hline HH Wealth & & & & & 0.98 & $(1.0)$ & 1.17 & $(1.46)$ \\
\hline Parents Entp. & 0.002 & $(0.05)$ & -0.04 & $(0.11)$ & -1.29 & $(2.76)$ & -4.58 & $(4.01)$ \\
\hline Age & -0.002 & $(0.003)$ & -0.01 & $(0.01)$ & -0.02 & $(0.14)$ & 0.12 & $(0.22)$ \\
\hline Female & -0.06 & $(0.05)$ & $-0.22 *$ & $(0.11)$ & -2.10 & $(2.71)$ & $-8.60 *$ & (4.04) \\
\hline Married & $-0.12 *$ & $(0.05)$ & $-0.21 \dagger$ & $(0.11)$ & -0.22 & $(2.83)$ & 3.67 & (4.19) \\
\hline In Development & 0.07 & (0.09) & 0.17 & $(0.22)$ & 0.88 & $(4.73)$ & 6.34 & $(7.85)$ \\
\hline In Testing & 0.14 & (0.09) & 0.10 & $(0.21)$ & $7.92 \dagger$ & $(4.62)$ & 10.53 & (7.19) \\
\hline Completed & 0.11 & $(0.08)$ & 0.28 & $(0.19)$ & $12.14 * *$ & $(4.0)$ & 9.46 & $(6.52)$ \\
\hline South & $0.14 \dagger$ & $(0.08)$ & -0.16 & $(0.15)$ & 5.64 & $(3.45)$ & -3.41 & $(5.45)$ \\
\hline Midwest & 0.11 & $(0.08)$ & -0.20 & $(0.17)$ & -0.86 & (3.98) & -1.45 & $(5.86)$ \\
\hline West & 0.02 & $(0.08)$ & -0.08 & $(0.17)$ & -0.95 & $(3.85)$ & -9.28 & (5.97) \\
\hline Intercept & -0.16 & $(0.18)$ & 0.21 & $(0.42)$ & $-46.69^{*}$ & (18.73) & 10.96 & (34.77) \\
\hline F-Stat & $1.87 *$ & & $1.61 \dagger$ & & $3.99^{* * *}$ & & 1.37 & \\
\hline Adjusted- $\mathrm{R}^{2}$ & 0.03 & & 0.06 & & 0.18 & & 0.04 & \\
\hline $\mathrm{n}$ & 415 & & 135 & & 219 & & 142 & \\
\hline
\end{tabular}

\footnotetext{
${ }^{\mathrm{a}}$ Standard errors are reported in parentheses. $\dagger p<0.10$; $* p<0.05 ; * * p<0.01 ; * * * p<0.001$, two tailed tests.
} 
TABLE 4

Results of Regressions of Investment Risk ${ }^{\text {a }}$

\begin{tabular}{|c|c|c|c|c|c|c|c|c|c|c|}
\hline \multirow{3}{*}{$\begin{array}{l}\text { Variables } \\
\text { ESE }\end{array}$} & \multirow{2}{*}{\multicolumn{2}{|c|}{$\begin{array}{c}\text { Bitler et al. (2005) } \\
\text { Model } 1\end{array}$}} & \multirow{2}{*}{\multicolumn{2}{|c|}{$\frac{\text { Li et al. (2004) }}{\text { Model } 2}$}} & \multirow{2}{*}{\multicolumn{2}{|c|}{$\begin{array}{c}\text { Industry Death Rate } \\
\text { Model } 3\end{array}$}} & \multirow{2}{*}{\multicolumn{2}{|c|}{$\frac{\text { R\&D a Major Priority }}{\text { Model } 4}$}} & \multirow{2}{*}{\multicolumn{2}{|c|}{$\begin{array}{c}\text { Venture High-Tech } \\
\text { Model } 5\end{array}$}} \\
\hline & & & & & & & & & & \\
\hline & 0.000 & $(0.013)$ & 0.012 & $(0.010)$ & $0.013 \dagger$ & $(0.008)$ & 0.183 & $(0.190)$ & -0.068 & $(0.175)$ \\
\hline Risk Preference & -0.019 & $(0.041)$ & -0.008 & $(0.034)$ & 0.007 & $(0.032)$ & 0.701 & $(0.536)$ & 0.502 & $(0.528)$ \\
\hline College & 0.013 & $(0.018)$ & 0.020 & $(0.016)$ & 0.009 & $(0.014)$ & $-0.038 \dagger$ & $(0.253)$ & 0.109 & $(0.245)$ \\
\hline Mgr. Exp. & 0.012 & $(0.009)$ & 0.006 & $(0.008)$ & 0.007 & $(0.006)$ & 0.083 & $(0.134)$ & -0.026 & $(0.127)$ \\
\hline HH Income & -0.003 & $(0.011)$ & 0.003 & $(0.007)$ & -0.004 & $(0.010)$ & -0.190 & $(0.136)$ & -0.205 & $(0.139)$ \\
\hline HH Wealth & 0.003 & $(0.007)$ & 0.002 & $(0.005)$ & -0.001 & $(0.004)$ & -0.048 & $(0.086)$ & 0.050 & $(0.085)$ \\
\hline Parents Entp. & -0.002 & $(0.017)$ & -0.0004 & $(0.014)$ & 0.001 & $(0.012)$ & 0.121 & $(0.229)$ & 0.320 & $(0.226)$ \\
\hline Age & $-0.002 * *$ & $(0.001)$ & $-0.002 * *$ & $(0.001)$ & 0.0002 & $(0.001)$ & -0.014 & $(0.012)$ & -0.017 & $(0.012)$ \\
\hline Female & -0.010 & $(0.017)$ & $-0.027 \dagger$ & $(0.014)$ & $-0.021 *$ & $(0.013)$ & $-0.400 \dagger$ & $(0.232)$ & $-0.882 * * *$ & $(0.230)$ \\
\hline South & 0.0001 & $(0.023)$ & -0.015 & $(0.019)$ & -0.001 & $(0.017)$ & 0.495 & $(0.331)$ & 0.271 & $(0.310)$ \\
\hline Midwest & 0.026 & $(0.025)$ & -0.022 & $(0.021)$ & 0.029 & $(0.018)$ & 0.332 & $(0.354)$ & -0.483 & $(0.349)$ \\
\hline West & 0.037 & $(0.025)$ & 0.014 & $(0.022)$ & -0.015 & $(0.019)$ & 0.499 & $(0.365)$ & 0.283 & $(0.342)$ \\
\hline Intercept & $0.914 * * *$ & $(0.116)$ & $0.280 * *$ & $(0.087)$ & 0.112 & $(0.101)$ & 1.031 & (1.627) & 1.892 & (1.619) \\
\hline $\begin{array}{l}\text {-2LogLikelihood } \\
\text { Model Chi- } \\
\text { Square }\end{array}$ & & & & & & & 477.10 & & $\begin{array}{l}488.56 \\
31.04 * *\end{array}$ & \\
\hline F-Stat & 0.99 & & 1.67 & & 1.31 & & & & & \\
\hline Adj. $R^{2}$ & 0.000 & & 0.022 & & 0.015 & & & & & \\
\hline Pseudo-R ${ }^{2}$ & & & & & & & 0.037 & & 0.073 & \\
\hline $\mathrm{n}$ & 390 & & 352 & & 245 & & 408 & & 410 & \\
\hline
\end{tabular}


TABLE 5

Results of Path Analysis ${ }^{a}$

\begin{tabular}{|c|c|c|c|c|}
\hline \multirow[b]{2}{*}{ Path } & \multicolumn{2}{|c|}{$\begin{array}{c}\text { Operating } \\
\text { Entrepreneur }\end{array}$} & \multicolumn{2}{|c|}{ Wealth Share } \\
\hline & Model & & Model & 2 \\
\hline 1. ESE - Dep. Var. & $0.131 * * *$ & $(0.03)$ & $0.082 *$ & $(0.03)$ \\
\hline 2. ESE - Risk Perc. & $5.715 * * *$ & $(1.43)$ & $5.800 * * *$ & $(1.43)$ \\
\hline 3. ESE - Scale & $0.379 * *$ & $(0.13)$ & $0.411 * *$ & $(0.13)$ \\
\hline 4. Risk Perc. - Dep. Var. & $0.002 *$ & $(0.001)$ & 0.000 & $(0.001)$ \\
\hline 5. Scale - Dep. Var. & $-0.041 \dagger$ & $(0.02)$ & 0.017 & $(0.02)$ \\
\hline RMSEA & 0.029 & & 0.028 & \\
\hline CFI & 0.97 & & 0.97 & \\
\hline Chi-Square & $6.258 \dagger$ & & 5.887 & \\
\hline p-value & 0.10 & & 0.12 & \\
\hline
\end{tabular}

${ }^{a}$ Standard errors are reported in parentheses. $\dagger p<0.10$; $* p<0.05$; ** $p$ $<0.01 ; * * * p<0.001$, two tailed tests. Path model is presented in Figure 1 . Model $\mathrm{DF}=3$ for models 1,2 and 3 
FIGURE 1

Path Diagram

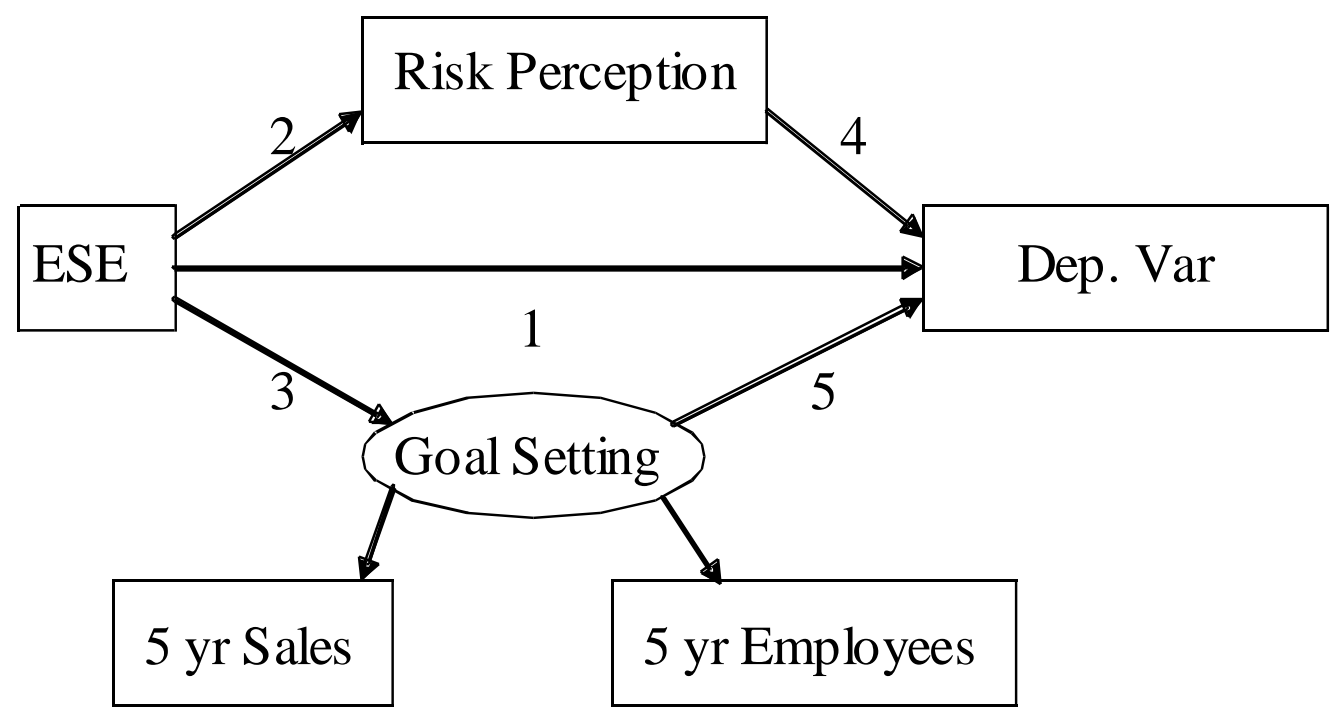




\section{Appendix A: Validity Study}

To investigate the construct validity of the measures used in this study, a validity study was undertaken. Surveys were administered to 148 undergraduate students enrolled in an introductory accounting course at a large, urban university in the northeast United States. After excluding surveys with missing or incomplete responses a final sample of 125, a response rate of 84.5 percent. The survey included measures of entrepreneurial self-efficacy (ESE) and risk preference (Risk Preference) used in the current field study. Additionally, the survey included established scales from the literature relating to the same or related constructs underlying the study.

These included the entrepreneurial self-efficacy (CGC ESE) scale from Chen et al. (1998), the generalized self-efficacy (GSE) scale from Sherer et al. (1982), the single-item selfesteem scale from Robins et al. (2001), the core self-evaluation scale from Judge et al. (2003), the chance and internal locus of control (LOC) scales from Levenson (1973), the overconfidence scale from Busenitz and Barney (1997) and Fischhoff and Lichtenstein (1977), the dispositional optimism scale from the Revised Life Orientation Test (Scheier, Carver, \& Bridges, 1994), and the risk taking (JPI-R Risk) scale from the Jackson Personality Index-Revised (Jackson, 1994). The descriptive statistics and correlations of the validity study are reported in Table A1. The mean and standard deviation of ESE and Risk Preference differ from those reported in Table 1 because Table A1 is based on the validity study sample, while Table 1 is based on the PSED sample. 
TABLE A1

Descriptive Statistics and Correlations for Validity Study Sample ${ }^{a}$

\begin{tabular}{|c|c|c|c|c|c|c|c|c|c|c|c|c|c|c|}
\hline Variables & Mean & $\begin{array}{l}\text { Std. } \\
\text { Dev. }\end{array}$ & 1 & 2 & 3 & 4 & 5 & 6 & 7 & 8 & 9 & 10 & 11 & 12 \\
\hline 1. ESE & 4.00 & 0.66 & $(0.78)$ & & & & & & & & & & & \\
\hline 2. Risk Preference & 0.40 & 0.24 & 0.23 & $(0.48)$ & & & & & & & & & & \\
\hline 3. CGC ESE & 3.70 & 0.54 & 0.53 & 0.27 & $(0.92)$ & & & & & & & & & \\
\hline 4. JPI-R Risk & -0.01 & 0.22 & 0.23 & 0.60 & 0.26 & $(0.81)$ & & & & & & & & \\
\hline 5. Overconfidence & 5.12 & 22.16 & 0.06 & 0.21 & 0.18 & 0.20 & - & & & & & & & \\
\hline 6. GSE & 0.42 & 0.51 & 0.21 & 0.14 & 0.37 & 0.14 & 0.07 & $(0.79)$ & & & & & & \\
\hline 7. $\mathrm{LOC}$ & 0.71 & 0.41 & 0.19 & 0.10 & 0.31 & -0.03 & 0.03 & 0.62 & $(0.65)$ & & & & & \\
\hline 8. Dispositional Optimism & 0.74 & 0.76 & 0.17 & 0.01 & 0.21 & 0.12 & 0.09 & 0.41 & 0.32 & $(0.76)$ & & & & \\
\hline 9. Self Esteem & 4.04 & 0.84 & 0.29 & 0.14 & 0.28 & 0.23 & 0.10 & 0.52 & 0.32 & 0.38 & - & & & \\
\hline 10. Core Self Evaluation & 0.73 & 0.57 & 0.30 & 0.14 & 0.36 & 0.15 & 0.06 & 0.67 & 0.48 & 0.37 & 0.61 & $(0.86)$ & & \\
\hline 11. Female & 0.44 & 0.50 & -0.18 & -0.12 & -0.12 & -0.35 & -0.21 & 0.01 & 0.12 & -0.16 & -0.12 & -0.17 & - & \\
\hline 12. Entrepreneurial Intent & 2.78 & 1.06 & 0.56 & 0.28 & 0.32 & 0.26 & 0.05 & -0.08 & -0.01 & 0.05 & 0.17 & 0.08 & -0.26 & $(0.83)$ \\
\hline
\end{tabular}

${ }^{a} n=125$. (Internal consistency on the diagonals). Values displayed are Pearson correlation coefficients. Coefficients with absolute values greater than 0.17,

0.22 , and 0.29 are significant at $0.05,0.01$, and 0.001 level (two-tailed), respectively. 